\title{
Phenotyping a Diverse Collection of Forage Sorghum Genotypes for Chilling Tolerance
}

\author{
Swarup Podder ${ }^{1}\left(\mathbb{O}\right.$, Dulan Samarappuli ${ }^{2}$, James V. Anderson ${ }^{3}(\mathbb{C})$ and Marisol T. Berti ${ }^{2, *}$ (i) \\ 1 Department of Crop and Soil Environmental Sciences, Virginia Polytechnic Institute and State University, \\ Blacksburg, VA 24061, USA; Swaruppodder@vt.edu \\ 2 Department of Plant Sciences, North Dakota State University, Fargo, ND 58108, USA; \\ Dulan.Samarappuli@ndsu.edu \\ 3 USDA/ARS, Sunflower and Plant Biology Research Unit, Edward T. Schafer Agricultural Research Center, \\ Fargo, ND 58102, USA; james.v.anderson@usda.gov \\ * Correspondence: Marisol.Berti@ndsu.edu; Tel.: +1-701-231-6110
}

Received: 4 June 2020; Accepted: 22 July 2020; Published: 25 July 2020

\begin{abstract}
Forage sorghum (FS) (Sorghum bicolor (L.) Moench) is a warm-season biomass crop used as forage for hay or silage with the potential to become a bioenergy feedstock or for dual-purpose (forage and energy). The objective of this study was to screen potential forage sorghum genotypes for increased chilling tolerance and biomass productivity. Seventy-one genotypes of FS were first ranked for high to low vigor index under controlled conditions at 24,12 , and $10^{\circ} \mathrm{C}$. Field experiments were also conducted on a subset of 12 genotypes in Fargo and Hickson, ND, USA, in 2017 and 2018, using two different seeding dates: early (10 May) and late (27 May). Field emergence index values were greater for the late-seeding compared with the early seeding date. Under field conditions, seed mortality and biomass yield were affected by the seeding date and biomass yield correlated with emergence index and normalized vegetative index. Chemical composition of forage sorghum biomass was not affected by the seeding dates. The results of this study suggest that some forage sorghum genotypes carry genetic traits for increased chilling tolerance and produce greater biomass yield when seeded earlier than normal, which could allow for breeding chilling tolerance into forage sorghum.
\end{abstract}

Keywords: bioenergy feedstock; emergence index; seed mortality; NDVI; biomass yield; nutritive value

\section{Introduction}

Forage sorghum (Sorghum bicolor (L.) Moench) is an annual biomass crop mainly grown for silage, hay and grazing forage. As an alternative crop to maize (Zea mays L.), it can also serve as a bioenergy feedstock for biogas, reducing negative environmental impact [1]. Research conducted in the North central region (NCR) has identified forage sorghum as the feedstock for energy (lignocellulosic to ethanol or biogas), with the most potential in this region [2-4]. Because forage sorghum is highly tolerant to heat and drought stress [5], requires low water input due to high-water use efficiency [6,7], and can be grown on marginal land with lower fertilizer input [8,9]. It is well suited to semi-arid conditions $[10,11]$. However, a main limitation of forage sorghum is its tolerance to temperatures below $15^{\circ} \mathrm{C}$, especially early in the growing season $[12,13]$. Consequently, in the NCR of the USA, planting of forage sorghum is limited by early-season soil temperatures, which usually do not reach an average of $15^{\circ} \mathrm{C}$ until two weeks later than maize planting. This limitation likely involves water imbibition and respiration of sorghum seeds, which slows down at suboptimal temperatures $\left(10^{\circ} \mathrm{C}\right)$ and is often a factor in germination failure [14]. Forage sorghum has the potential for greater biomass production, as lignocellulosic feedstock for energy, than maize in the NCR [2,3]; thus, improving chilling tolerance could increase biomass, acreage, and productivity of forage sorghum in the NCR. 
Although some information about chilling-tolerance in grain sorghum genotypes exists, there is limited information about chilling-tolerance in forage sorghum commercial cultivars and hybrids. There are a large number of chilling-tolerant grain sorghum lines well adapted to the Highlands of Honduras, Kenya, and Mexico, but poorly adapted to the northwestern USA, southern Canada, and West Germany $[15,16]$. Chinese grain sorghum lines such as Shan Qui Red, Kaoliang, Niu Sheng Zui, and Hong Ke Zi have chilling-tolerance genes [17-19]. However, because these lines generally lack other important agronomic traits, the grain sorghum reference lines BTx623, and SC265 are often used for chilling-sensitive studies in most US laboratories [17].

Many promising quantitative trait loci (QTL) associated with low temperature tolerance have also been identified in grain sorghum [20]. The QTL associated with maintenance of cell division and growth during chilling stress highlight potential prerequisites for improving chilling tolerance of sorghum genotypes [21]. Franks et al. [22] compared 10 Chinese Kaoliang accessions with 10 US inbred parental lines and 10 US commercial grain sorghum hybrids for the trait of chilling-tolerance under growth chamber and field conditions. Although Chinese lines had better performance than both inbred and hybrid US classes in laboratory germination and field emergence rate studies, US hybrids had greater final field stand counts and biomass yield than Chinese lines. These results suggested that Chinese accessions of grain sorghum are a favorable source of germplasm that could be utilized in breeding programs for introgression of early season chilling-tolerant germination traits/genes in grain and forage sorghum.

Phenotyping forage sorghum genotypes for germination rates under controlled conditions is an efficient way for identifying lines adapted to low temperature germination. Under laboratory conditions, a seven-day cold test at $10{ }^{\circ} \mathrm{C}$ was a useful predictor for increased emergence in the field, which identified eight novel accessions with potential superior alleles for chilling-tolerance [23]. Measuring shoot growth and germination rate at a controlled temperature of $15^{\circ} \mathrm{C}$ is helpful for screening genotypes for chilling-tolerance before final evaluation in the field [24]. Under field conditions, emergence and root establishment of forage sorghum early in the growing seasons also was a key determinant of chilling-tolerance [21]. However, it is important to note that results obtained from growth chamber performance at $15^{\circ} \mathrm{C}$ and field performance differed, which included emergence percentage, emergence index, shoot and root dry weight, seedling height, and vigor score [16]. Additionally, control and field studies including different seeding dates (early and late) to screen for chilling-tolerant sorghum genotypes, Kapanigowda et al. [25] identified significant differences in emergence percentage, emergence index, biomass yield, plants height, and leaf number. In that study, late-emerging genotypes produced greater biomass than early emerging genotypes.

Correlations between growth chamber and field studies for emergence index can be a useful method for screening chilling-tolerant forage sorghum genotypes. Under cold conditions, some controlled and field-grown sorghum lines had significantly higher emergence and seedling growth than the check chilling-tolerant Shan Qui Red genotype [26,27]. The survival and growth performance of sorghum seedlings under cold conditions positively correlated with emergence rate and root development in the field [21].

Chilling tolerant commercial cultivars of forage sorghum and sorghum $\times$ sudangrass (S. bicolor var. sudanense) hybrids are unknown. This study was aimed at identifying and selecting chilling-tolerant genotypes of commercial forage sorghum cultivars and hybrids for greater biomass potential as feedstock for bioenergy.

\section{Materials and Methods}

\subsection{Seed Germination Rate and Vigor Index Evaluation}

Sixty-one commercially cultivated forage sorghum or sorghum $\times$ sudan genotypes from different seed companies and 10 grain sorghum genotypes (two chilling-sensitive and eight chilling-tolerant) provided by Kansas State University, Manhattan, KS, USA were tested to measure germination rate. 
Seed germination rates were evaluated at $24{ }^{\circ} \mathrm{C}$ and $12{ }^{\circ} \mathrm{C}$ between 4 and 24 March, in 2017, and at $10^{\circ} \mathrm{C}$ between 1 and 21 February, in 2018, at the United States Department of Agriculture-Agricultural Research Service (USDA-ARS), Edward T. Schafer Agricultural Research Center in Fargo, ND, USA. In both runs, three Petri dishes with 50 seeds in each were evaluated for 20 days and arranged in a completely randomized design. Evaluations included germination rate, and vigor index. The vigor index at $12{ }^{\circ} \mathrm{C}$ and $10{ }^{\circ} \mathrm{C}$ were corrected by the baseline germination rate at $24^{\circ} \mathrm{C}$. In the second run, seeds were evaluated at $10^{\circ} \mathrm{C}$ instead of $12{ }^{\circ} \mathrm{C}$ to get better discrimination for vigor index among the genotypes. In the second run, seeds were not evaluated for baseline germination test at $24^{\circ} \mathrm{C}$, as seeds were stored at cold temperature $\left(4^{\circ} \mathrm{C}\right)$. Germination rate and vigor index was measured for $24^{\circ} \mathrm{C}$, $12{ }^{\circ} \mathrm{C}$, and $10^{\circ} \mathrm{C}$ using the following formula:

$$
\begin{gathered}
\text { Germination rate }(\%)=\frac{\text { No. seeds germinated }}{\text { No. seeds tested } * 100} \\
\text { Vigor index }=\frac{\text { No. seeds germinated at first counting }}{1}+ \\
\frac{\text { No. seeds germinated at second counting }}{2}+\cdots+\frac{\text { No. seeds germinated at day } n}{n} \\
\text { Corrected vigor index }=\text { Vigor index }\left(\text { at } 10 \text { or } 12^{\circ} \mathrm{C}\right) * \text { germination rate }\left(\text { at } 24^{\circ} \mathrm{C}\right) / 100
\end{gathered}
$$

In 2017, the eight genotypes ranking the highest in corrected vigor index were selected to test in the field. However, if among the first ranked genotypes two of them were from the same seed company, we skipped to the next highest ranked genotype from a different seed company source to avoid selecting genotypes with the same genetic base. In addition, "Forage King" (ranking the lowest in corrected vigor index) and two chilling-sensitive genotypes $(\mathrm{BT} \times 623$, and SC265) were selected as well, totaling 11 genotypes. In 2018, after the second run of germination, a few of the genotypes selected in 2017, had different corrected vigor index rankings. Thus, a few new genotypes were included in the 2018 field trial, as well as eliminating those which did not perform well in the 2017 field experiments. In 2018, nine genotypes with the highest corrected vigor index, one genotype with the lowest corrected vigor index (Forage King) and two check chilling-tolerant genotypes (Niu Sheng Zui and Kaoliang) were selected for field trials in 2018. Six of the genotypes were common in the both years of field experiments.

\subsection{Field Establishment and Experimental Design}

Experiments were conducted in 2017 and 2018 at the North Dakota State University (NDSU) research site in Fargo, ND, USA $\left(46^{\circ} 897989^{\prime} \mathrm{N},-96^{\circ} 817342^{\prime} \mathrm{W}, 274\right.$ m elevation) and in Hickson, ND, USA ( $46^{\circ} 634^{\prime} \mathrm{N},-96^{\circ} 838^{\prime} \mathrm{W}, 280 \mathrm{~m}$ elevation). The soil type in Fargo is Fargo-Ryan silty clay soil, and the soil type in Hickson is Fargo-Hegne silty clay, (Fargo: fine, montmorillonitic, frigid, Vertic Haplaquol with a leached and degraded nitric horizon; Ryan: fine, smectitic, frigid Typic Natraquerts; Hegne: fine, smectitic, frigid Typic Calciaquerts) [28]. Rainfall and daily temperature were recorded by the North Dakota Agricultural Weather Network (NDAWN) [29] at both sites (Figure 1).

A composite (include three separate soil cores) soil sample was collected from each replicate at $0-15 \mathrm{~cm}$ and $15-60 \mathrm{~cm}$ in depth in each site before seeding; in total four composite samples per site, using a closed tube, hand-held soil probe. Soil samples from $0 \mathrm{~cm}$ to $15 \mathrm{~cm}$ were tested for $\mathrm{pH}$, organic matter $(\mathrm{OM})$, soil nitrate $\left(\mathrm{NO}_{3}-\mathrm{N}\right)$, phosphorus $(\mathrm{P})$, and potassium $(\mathrm{K})$ by the North Dakota State University (NDSU) Soil Testing Laboratory (Fargo, ND, USA) [30]. The nitrate $\left(\mathrm{NO}_{3}-\mathrm{N}\right)$ analysis was the only test performed on the soil samples taken at the $15-60 \mathrm{~cm}$ depth (Table 1). Soil samples were tested using the following methods: (i) organic matter, loss on ignition; (ii) $\mathrm{NO}_{3}-\mathrm{N}$, colorimetric determination by trans-nitration of salicylic acid method [31,32]; (iii) P Olsen procedure using a Brinkmann PC 910 colorimeter (Brinkmann Instruments, Westbury, NY, USA) [33]; and (iv) K ammonium acetate method using a Buck Scientific Model 210 VGP atomic absorption spectrophotometer (Buck Scientific, East Norwalk, CT, USA) [34]. 

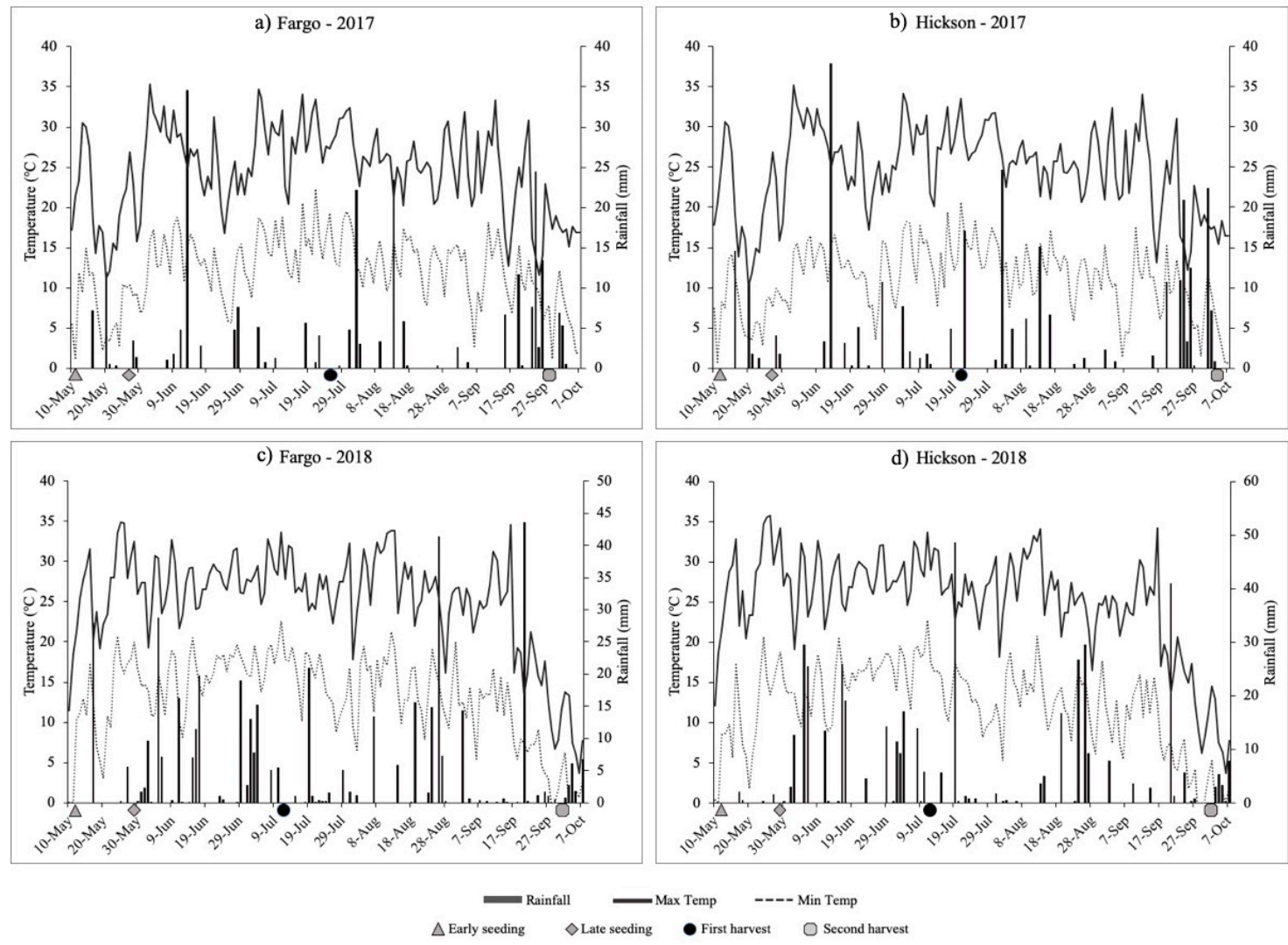

Figure 1. Air temperature and rainfall distribution (rainfall events indicated in grey bars) at four environments at (a) Fargo 2017, (b) Fargo 2018, (c) Hickson, 2017, and (d) Hickson 2018, ND, USA.

Table 1. Soil analysis before seeding at Fargo and Hickson, ND, USA in 2017 and 2018.

\begin{tabular}{|c|c|c|c|c|c|c|}
\hline Environment & Soil depth & $\mathrm{NO}_{3}-\mathrm{N} \ddagger$ & $\mathbf{P}$ & $\mathbf{K}$ & $\mathrm{pH}$ & OM \\
\hline & $\mathrm{Cm}$ & $\mathrm{kg} \mathrm{ha}^{-1}$ & \multicolumn{2}{|c|}{$\mathrm{mg} \mathrm{kg}^{-1}$} & & $\mathrm{mg} \mathrm{kg}^{-1}$ \\
\hline \multicolumn{7}{|l|}{2017} \\
\hline \multirow[t]{2}{*}{ Fargo } & $0-15$ & 58 & 36 & 348 & 7.50 & 67 \\
\hline & $15-60$ & 108 & - & - & - & - \\
\hline \multirow[t]{2}{*}{ Hickson } & $0-15$ & 18 & 6 & 380 & 7.80 & 59 \\
\hline & $15-60$ & 30 & - & - & - & - \\
\hline \multicolumn{7}{|l|}{2018} \\
\hline \multirow[t]{2}{*}{ Fargo } & $0-15$ & 47 & 18 & 324 & 7.48 & 71 \\
\hline & $15-60$ & 81 & - & - & - & - \\
\hline \multirow[t]{2}{*}{ Hickson } & $0-15$ & 22 & 12 & 330 & 7.40 & 55 \\
\hline & $15-60$ & 20 & - & - & - & - \\
\hline
\end{tabular}

${ }^{\ddagger} \mathrm{pH}$, organic matter $(\mathrm{OM})$, phosphorus $(\mathrm{P})$, potassium $(\mathrm{K})$, nitrate nitrogen $\left(\mathrm{NO}_{3}-\mathrm{N}\right)$.

The experiment was a randomized complete block design (RCBD) with a split-plot arrangement and four replicates. The main plot was the seeding date (early and late), and the sub-plot was the selected genotypes. The previous crops were wheat (Triticum aestivum L.) and soybean (Glycine max (L.) Merr.) at Fargo and Hickson, respectively, in 2016 and 2017. Early seeding was done on 10 May, in 2017 and in 2018 and late seeding was done on 27 May in 2017 and 29 May in 2018. The plots size was $7.62 \mathrm{~m}$ long with four rows 0.15-m apart. A four-cone continuous plot drill XL (Wintersteiger, Salt Lake City, UT, USA) was used. Seeding rate for each genotype was 190,190 pure live seeds ha ${ }^{-1}$ calculated to target 
172,900 plants ha $^{-1}$. For all genotypes, 1000 -seed weight was measured to calculate the exact number of live seeds needed per row. Pure live seeds were calculated using the germination percentage obtained in growth chamber experiments. Seeds were sown to $2.5 \mathrm{~cm}$ depth.

Forage biomass was harvested two times. First harvest was done on 20 July and on 27 July in 2017 at Hickson and Fargo, respectively, and on 12 July in 2018 at both sites. All the genotypes planted in either date were harvested at the same time. Plant stalks were allowed to regrow and harvested for second time on 28 September and 6 October in 2017 at Fargo and Hickson, respectively. In 2018, the second harvest was done on 1 October at both locations.

The Hickson experiment site was fertilized with $80 \mathrm{~kg} \mathrm{~N} \mathrm{ha}^{-1}$ and $50 \mathrm{~kg} \mathrm{P}_{2} \mathrm{O}_{5} \mathrm{ha}^{-1}$ before seeding in 2017 and 2018. The Fargo experiment site was fertilized with $60 \mathrm{~kg} \mathrm{~N} \mathrm{ha}^{-1}$ at the V-5 stage of sorghum, as side dressing in 2017 and 2018. The Fargo experiment site was fertilized later with lower rate as initial soil test report showed higher $\mathrm{NO}_{3}-\mathrm{N}$ content than Hickson site. No K was applied in any experimental sites since soil test results were above $200 \mathrm{mg} \mathrm{kg}^{-1}$, which is considered an adequate level [30]. Weed pressure was greater at the Fargo site compared with the Hickson site. At Hickson, the most common weeds were common mallow (Malva neglecta L.), green foxtail (Setaria viridis L.), Canada thistle (Cirsium arvense (L.) Scop.), and field bindweed (Convolvulus arvensis L.). At the Fargo site, weeds were mostly pigweed (Amaranthus retroflexus L.). The fourth replicate area of early seeding genotypes was affected by high pressure of field bindweed at the Fargo site in 2018. In 2017, hand weeding was done twice at the Fargo site and one time at the Hickson site. In addition, 2,4 dichlorophenoxyacetic acid $(2,4 \mathrm{D})$ was sprayed at the V-3 stage of sorghum with a rate of $270 \mathrm{~g}$ active ingredient (a.i.) ha ${ }^{-1}$ at the Fargo site in 2017 and 2018.

\section{Air Temperature and Rainfall}

Average air temperature was lower at seeding time in 2017 compared with 2018. At emergence period, average air temperature was below $15^{\circ} \mathrm{C}$ for twelve days in 2017 (Figure 1a,b) and five days in 2018 (Figure 1c,d). At the end of the season, average air temperature decreased below $15^{\circ} \mathrm{C}$ on 23 September in 2017 and 17 September in 2018. There was less rainfall in 2017 (Figure 1a,b) compared with 2018 (Figure 1c,d). From seeding to final harvesting, total rainfall was $246 \mathrm{~mm}$ at Fargo and $284 \mathrm{~mm}$ at Hickson in 2017 (Figure 1a,b) and $405 \mathrm{~mm}$ at Fargo and $425 \mathrm{~mm}$ at Hickson in 2018 (Figure 1c,d) [29].

A sensor (5TM water content and temperature sensors, Decagon Devices, Inc., Pullman, WA, USA) was set in the field at $2.5-3.5 \mathrm{~cm}$ depth at the level of seed to record the soil temperature and soil water content. The sensor has four probes, which were set in a representative way within the plot. The sensor recorded the hourly soil temperature and soil water content throughout the growing season.

One linear meter of each two-center rows was marked for counting the emerged plants. Within the marked area, emerged plants were counted from five days after seeding (DAS) and continued up to 15 DAS. Emergence index was calculated using the following formula:

$$
\begin{gathered}
\text { Emergence index }=\frac{\text { No. plants emerged at first counting }}{1}+ \\
\frac{\text { No. plants emerged at second counting }}{2}+\cdots+\frac{\text { No. plants emerged at day } n}{n}
\end{gathered}
$$

CANOPEO (a free mobile application developed by Oklahoma State University, Stillwater, OK, USA, to measure canopy) was used to measure the canopy coverage at early vegetative stage [35]. One picture was taken from each experimental unit from the same level of height with an Android phone. Those pictures were analyzed in a computer-based CANOPEO application to measure the percentage of green coverage within a selected area.

The number of plants was counted within one linear meter of each two-center rows at 20 days after each seeding. To calculate stand establishment, total number of counted plants within the two-linear meters was converted to plants per hectare. Seed mortality was calculated using the following formula: 


$$
\text { Mortality }(\%)=100-\frac{(190,190-\text { stand establishment })}{190,190 * 100}
$$

Normalized difference vegetation index (NDVI) was measured using a handheld GreenSeeker (Trimble Inc., Sunnyvale, CA, USA) at 49 days after seeding (DAS) in 2017 and 2018. The GreenSeeker instrument was run above the center-row of each sampling-plot. The NDVI is a measurement of plant health based on how a plant reflects sun light at specific wavelengths. To be more specific, NDVI $(656,774)$ is a measurement of the reflectivity of plants expressed as

$$
N D V I=\frac{N I R-V I S}{(N I R+V I S)}
$$

where NIR = near-infrared reflectivity at $774 \mathrm{~nm}$ and VIS $=$ red reflectivity at $656 \mathrm{~nm}$.

Photosynthetically active radiation (PAR) readings under and above the canopy were collected at 58 DAS in 2017 and 2018 by placing a ceptometer in between the two-center rows. Three readings were taken from each experimental unit and the ceptometer provided the average readings. Intercepted PAR light percentage was calculated using the following formula:

$$
\text { Intercepted PAR light }(\%)=\frac{(\text { PAR above the canopy }- \text { PAR below the canopy })}{\text { PAR above the canopy } * 100}
$$

Plant height was measured before each harvest from each sub-plot. Plant height was measured with a measuring stick from the ground level to top level of the arch of the uppermost leaf whose tip is pointing down. Plants growing stage was recorded during each harvest.

The two-center rows of each sub-plot were harvested with a flail forage harvester (Carter, Brookston, IN) in the first harvest, leaving $15 \mathrm{~cm}$ of stubble to allow regrowth. The second harvest was done cutting stalks by hand with a scythe. Total harvested fresh biomass weight from each sub-plot was recorded and then about $1 \mathrm{~kg}$ of fresh biomass sample was taken to calculate dry biomass yield. After recording fresh weight, samples were allowed to dry for two weeks in a drier at $45^{\circ} \mathrm{C}$. Dry matter content and dry biomass yield were calculated using the following formula.

$$
\begin{gathered}
\text { Dry matter content }=\frac{\text { Dry weight }}{\text { Fresh weight }} * 100 \\
\text { Dry biomass yield }=\frac{\text { Total harvested fresh weight } * \text { Dry matter content }}{100}
\end{gathered}
$$

Dried biomass samples were ground to a 1-mm mesh with a mill (Wiley Mill Standard Model $N^{\circ} 3$, Philadelphia, PA, USA). Samples of the first harvest in 2017 were analyzed at the Animal Sciences laboratory at NDSU, Fargo, ND, USA, to measure N content using the Kjeldahl method [36]; crude protein (CP) according to Association of Official Agricultural Chemists (AOAC) Method 2001.11; neutral detergent fiber (NDF) according to ANKOM, 2011.A200 (ANKOM Technology, Macedon, NY, USA) Method 6); acid detergent fiber (ADF) according to ANKOM, 2011 A200 Method 5); acid detergent lignin (ADL); and ash according to AOAC Method 942.05. With these wet chemistry data, a calibration was created for forage sorghum biomass samples in an XDS near-infrared reflectance (NIR) rapid content analyzer (Foss, Denmark), following the methods described by Abrams et al. [37]. Samples falling off the calibration ranges in 2018 were sent to the laboratory for wet chemistry analysis. Nitrogen accumulation was calculated by multiplying nitrogen content in biomass by the dry matter yield.

\subsection{Data Analysis}

The germination rate and corrected vigor index data were analyzed with statistical analysis software (SAS) [38] using MIXED procedure to identify chilling-tolerant genotypes from non-chilling tolerant genotypes. The statistical analysis was done separately by run and then combined. Temperature, 
genotype, and run were fixed effects and replicate was a random effect. Treatment means separation was determined by F-protected least significant difference (LSD) comparisons at the $p \leq 0.05$ probability level.

All the field data collected throughout the season were analyzed separately by year and location. Homogeneity of variance tests were done to determine if environments (defined as the combination of location-year) could be combined. If homogeneous, a combined analysis across four environments was conducted. To determine the difference among those treatments, F-protected least squared differences with a significance of $95 \%$ level of confidence were used. Regression analysis was used to determine the biomass yield. Linear regression model was used where independent variables were emergence index and NDVI, and dependent variable was biomass yield.

Soil Temperature and Soil Water Content from Planting to Emergence

Soil temperature at emergence was lower for early seeded genotypes than genotypes seeded two weeks later (Figure 2a-d). In 2018, soil temperature was higher than in 2017 during emergence. In 2018, fluctuation of day and night temperature was greater at planting. Though soil temperature was above the base temperature for sorghum $\left(15^{\circ} \mathrm{C}\right)$ at planting, at the Fargo site in 2018 (Figure 2c,d), emergence did not occur, as soil water content was very low $\left(<200 \mathrm{~g} \mathrm{~kg}^{-1}\right)$. Early seeded genotypes were exposed to cold temperatures (below base temperature) at the beginning of the season for twelve days in 2017 (Figure 2a,b) and only six days in 2018 (Figure 2c,d), while late-seeded genotypes were exposed to temperatures below base temperature for only two days in 2017 (Figure 2a,b). For the late-seeded genotypes, soil temperature was above the base temperature at seeding in both 2017 and 2018 (Figure 2a-d).
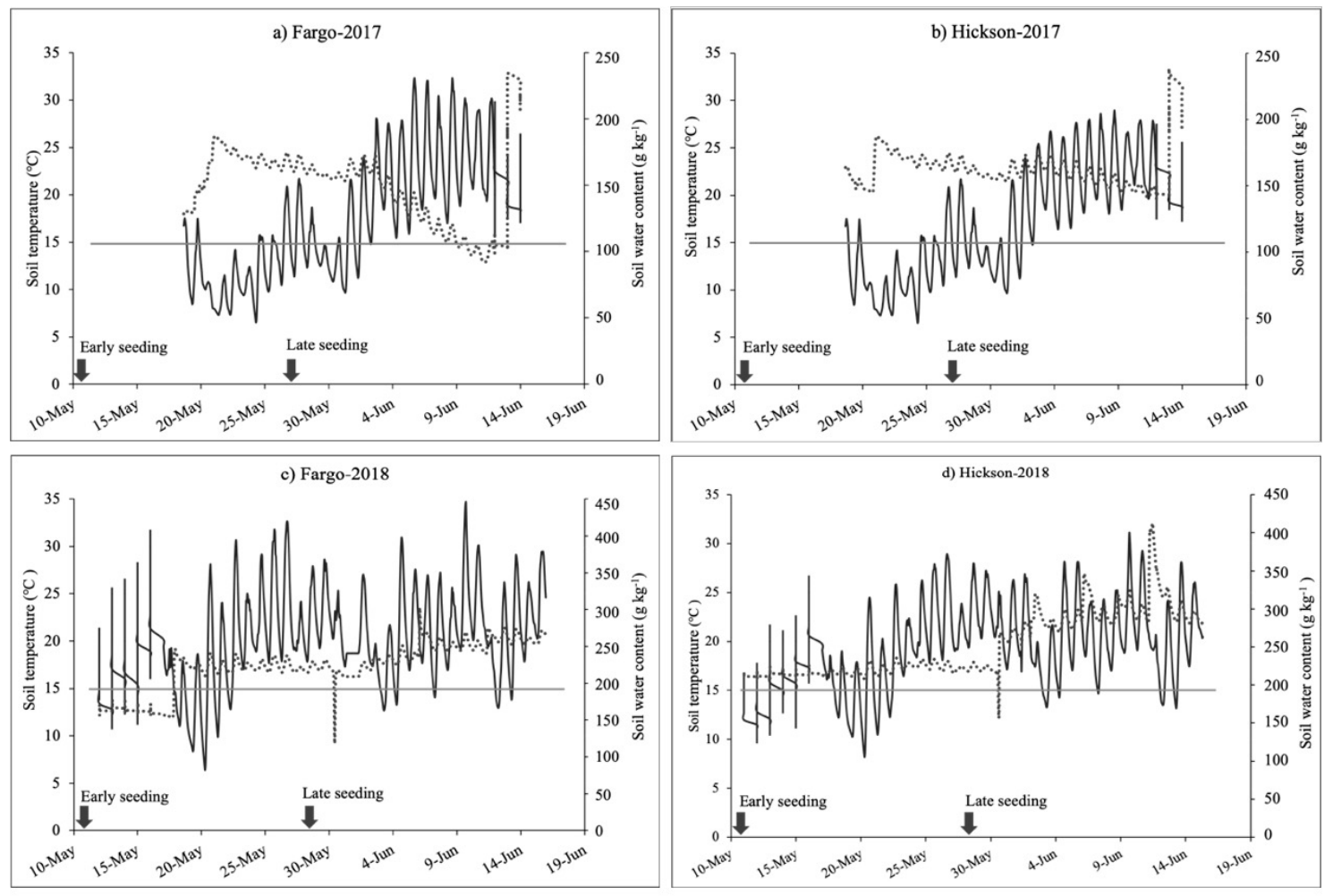

Base temperature

- Soil temperature

Soil water content

Figure 2. Soil temperature and soil water content from planting to the end of emergence at four environments at (a) Fargo 2017, (b) Hickson 2017, (c) Fargo, 2018, and (d) Hickson 2018, ND, USA. 


\section{Results and Discussion}

\subsection{Growth Chamber Seed Germination and Vigor Index}

Sorghum genotypes varied in germination rate and vigor index at 24,12 , and $10{ }^{\circ} \mathrm{C}$ (Table 2). The ranges of germination rate were 52 to $100 \%$ at $24{ }^{\circ} \mathrm{C}, 32.7$ to $100 \%$ at $12{ }^{\circ} \mathrm{C}$, and 6.7 to $99.3 \%$ at $10^{\circ} \mathrm{C}$. Germination rates were greater at $24^{\circ} \mathrm{C}$, as that is the optimum temperature for germination of forage sorghum [39]. The range of corrected vigor indices were 5.2 to 25.0 at $12{ }^{\circ} \mathrm{C}$, and 0.7 to 17.8 at $10^{\circ} \mathrm{C}$. Based on the corrected vigor index at $12{ }^{\circ} \mathrm{C}$ and $10^{\circ} \mathrm{C}$, genotypes were ranked from highest to lowest. At $12{ }^{\circ} \mathrm{C}$, corrected vigor indices were statistically indistinguishable $(p \geq 0.05)$ for the 1 to 48 ranked genotypes. In the second year of the study, the temperature was decreased to $10{ }^{\circ} \mathrm{C}$ to exert more cold stress on genotypes. The results produced at $10^{\circ} \mathrm{C}$ indicated that only eight genotypes had the same corrected vigor index $(p \geq 0.05)$ as the highest ranked genotype. Only six genotypes ranked among the top 11 genotypes at both temperatures, $12{ }^{\circ} \mathrm{C}$ and $10^{\circ} \mathrm{C}$. Temperatures below $15^{\circ} \mathrm{C}$ are considered a cold stress condition in sorghum, which drastically reduces the seed germination rate and seedling growth [12,13]. Razmi et al. [12] observed 50\% germination reduction, vigor index reduction, and a 10.5 days delay in germination at $11 / 8^{\circ} \mathrm{C}$ (day/light) compared with a $25 / 22{ }^{\circ} \mathrm{C}$ regime in three sorghum genotypes conducted under growth chamber conditions.

Table 2. Mean seed germination and corrected vigor index of forage sorghum genotypes evaluated at different temperatures in controlled environment growth chambers in 2017 and 2018.

\begin{tabular}{|c|c|c|c|c|c|c|c|c|c|}
\hline \multirow{2}{*}{ Genotypes } & \multirow{2}{*}{ SorghumType } & \multirow{2}{*}{$\begin{array}{l}\text { Fungicide } \\
\text { Treated Seed }\end{array}$} & \multicolumn{2}{|c|}{ Germination (\%) } & \multirow[b]{2}{*}{$10^{\circ} \mathrm{C}$} & \multirow[b]{2}{*}{$12{ }^{\circ} \mathrm{C}$} & \multicolumn{3}{|c|}{ Corrected Vigor Index } \\
\hline & & & $24^{\circ} \mathrm{C}$ & $12{ }^{\circ} \mathrm{C}$ & & & Rank $_{12}{ }^{\circ} \mathrm{C}$ & $10^{\circ} \mathrm{C}$ & Rank $_{10}{ }^{\circ} \mathrm{C}$ \\
\hline SPX-901 ab & FSH & $\mathrm{Y}$ & 96.7 & 99.3 & 97.3 & $25.1^{+}$ & 1 & 16.2 & 4 \\
\hline CHR-FS4 & FS & $\mathrm{Y}$ & 96.0 & 97.3 & 96.7 & 25.0 & 2 & 14.9 & 14 \\
\hline $\mathrm{BT} \times 623^{\mathrm{a}}$ & GS & $\mathrm{N}$ & 98.7 & 98.7 & 82.7 & 25.0 & 3 & 10.6 & 45 \\
\hline Sordan Headless ${ }^{b}$ & SxS & $\mathrm{Y}$ & 97.3 & 98.7 & 94.7 & 24.9 & 4 & 15.7 & 8 \\
\hline Pampa Triunfo XLT ${ }^{\text {ab }}$ & SxS & $\mathrm{Y}$ & 94.7 & 97.3 & 95.3 & 24.6 & 5 & 17.8 & 1 \\
\hline NK300 b & FSH & $\mathrm{Y}$ & 98.0 & 98.7 & 98.7 & 24.4 & 6 & 16.6 & 2 \\
\hline SPX3952 & SxS & $\mathrm{Y}$ & 94.0 & 96.0 & 90.7 & 24.4 & 7 & 15.0 & 13 \\
\hline Hay King ab & $\mathrm{Su}$ & $\mathrm{Y}$ & 100.0 & 100.0 & 98.0 & 24.4 & 8 & 14.8 & 16 \\
\hline $\mathrm{SC} 265^{\mathrm{a}}$ & GS & $\mathrm{N}$ & 99.3 & 98.7 & 53.3 & 24.2 & 9 & 5.4 & 64 \\
\hline Pampa Verde BMR $6^{\text {b }}$ & SxS & $\mathrm{Y}$ & 98.0 & 96.7 & 96.7 & 24.2 & 10 & 16.2 & 5 \\
\hline $1990^{\mathrm{ab}}$ & FSH & $\mathrm{Y}$ & 99.3 & 97.3 & 98.0 & 24.0 & 11 & 16.5 & 3 \\
\hline CHR-FS3 & FS & $\mathrm{Y}$ & 99.3 & 99.3 & 96.7 & 23.9 & 12 & 12.3 & 30 \\
\hline $54126^{a}$ & SW & $\mathrm{Y}$ & 90.0 & 94.0 & 86.7 & 23.9 & 13 & 12.2 & 31 \\
\hline SPX-28313 & FSH & $\mathrm{Y}$ & 91.3 & 94.0 & 92.0 & 23.9 & 14 & 15.0 & 12 \\
\hline CHR-SS2 & SxS & $\mathrm{Y}$ & 95.3 & 96.0 & 86.0 & 23.9 & 15 & 11.5 & 40 \\
\hline X94Z & FS & $\mathrm{Y}$ & 96.0 & 96.7 & 94.7 & 23.8 & 16 & 11.7 & 38 \\
\hline Hong Ke Zi & GS & $\mathrm{N}$ & 84.0 & 88.7 & 73.3 & 23.8 & 17 & 7.0 & 59 \\
\hline SPX 902 & FSH & $\mathrm{Y}$ & 97.3 & 95.3 & 92.0 & 23.8 & 18 & 12.9 & 24 \\
\hline SDH2942 BMR & SxS & Y & 100.0 & 98.0 & 90.0 & 23.6 & 19 & 10.5 & 47 \\
\hline Niu Sheng Zui ${ }^{b}$ & GS & $\mathrm{N}$ & 87.3 & 92.7 & 80.7 & 23.6 & 20 & 9.2 & 50 \\
\hline SPX 903 & FSH & $\mathrm{Y}$ & 95.3 & 96.7 & 90.6 & 23.5 & 21 & 12.1 & 32 \\
\hline Sweetie BMR ${ }^{\text {ab }}$ & SW & $\mathrm{Y}$ & 96.0 & 96.0 & 99.3 & 23.5 & 22 & 15.2 & 9 \\
\hline Shan Qui Red & GS & $\mathrm{Y}$ & 98.0 & 99.3 & 70.7 & 23.5 & 23 & 6.6 & 61 \\
\hline 36126 & SW & $\mathrm{Y}$ & 89.3 & 91.3 & 84.7 & 23.4 & 24 & 13.2 & 23 \\
\hline Green Treat $128^{a}$ & SxS & $\mathrm{Y}$ & 98.7 & 95.3 & 96.7 & 23.4 & 25 & 14.7 & 17 \\
\hline Brachytic sorghum $^{a}$ & FS & $\mathrm{Y}$ & 97.3 & 96.0 & 86.7 & 23.4 & 26 & 12.1 & 33 \\
\hline SPX 904 & FSH & $\mathrm{Y}$ & 92.7 & 88.7 & 87.3 & 23.3 & 27 & 16.0 & 7 \\
\hline SPX-3402 & FS & $\mathrm{Y}$ & 97.3 & 96.7 & 93.3 & 23.3 & 28 & 15.0 & 11 \\
\hline Pampa Karamelo & SW & $\mathrm{Y}$ & 94.0 & 95.3 & 90.0 & 23.2 & 29 & 12.0 & 34 \\
\hline 36111 & SW & $\mathrm{Y}$ & 93.3 & 90.0 & 90.7 & 23.2 & 30 & 14.2 & 19 \\
\hline CHR-FS9 & FS & $\mathrm{Y}$ & 98.7 & 96.0 & 98.0 & 23.0 & 31 & 15.1 & 10 \\
\hline
\end{tabular}


Table 2. Cont.

\begin{tabular}{|c|c|c|c|c|c|c|c|c|c|}
\hline \multirow{2}{*}{ Genotypes } & \multirow{2}{*}{ SorghumType } & \multirow{2}{*}{$\begin{array}{l}\text { Fungicide } \\
\text { Treated Seed }\end{array}$} & \multicolumn{2}{|c|}{ Germination (\%) } & \multirow[b]{2}{*}{$10^{\circ} \mathrm{C}$} & \multirow[b]{2}{*}{$12{ }^{\circ} \mathrm{C}$} & \multicolumn{3}{|c|}{ Corrected Vigor Index } \\
\hline & & & $24^{\circ} \mathrm{C}$ & $12{ }^{\circ} \mathrm{C}$ & & & $\operatorname{Rank}_{12}{ }^{\circ} \mathrm{C}$ & $10^{\circ} \mathrm{C}$ & Rank $_{10}{ }^{\circ} \mathrm{C}$ \\
\hline Honey Sweet & SxS & $\mathrm{Y}$ & 97.3 & 96.7 & 97.3 & 22.9 & 32 & 12.8 & 26 \\
\hline BMR 105 & FS & $\mathrm{Y}$ & 97.3 & 98.0 & 96.6 & 22.9 & 33 & 13.2 & 22 \\
\hline SS405 & FSH & $\mathrm{Y}$ & 90.7 & 92.0 & 85.3 & 22.9 & 34 & 12.5 & 28 \\
\hline SCI 1345 & GS & $\mathrm{N}$ & 94.7 & 98.0 & 87.9 & 22.8 & 35 & 10.5 & 46 \\
\hline Greentreat Dynamo & SxS & $\mathrm{Y}$ & 99.3 & 98.7 & 98.0 & 22.5 & 36 & 12.8 & 25 \\
\hline Kaoliang ${ }^{b}$ & GS & $\mathrm{N}$ & 98.0 & 96.0 & 85.3 & 22.5 & 37 & 8.1 & 54 \\
\hline Pampa Centurion & FS & $\mathrm{Y}$ & 91.3 & 93.3 & 83.3 & 22.5 & 38 & 11.5 & 41 \\
\hline AL 31 BMR & SxS & $\mathrm{Y}$ & 80.7 & 84.0 & 74.0 & 22.4 & 39 & 11.8 & 37 \\
\hline BMR 106 & FS & $\mathrm{Y}$ & 96.7 & 91.3 & 89.3 & 22.4 & 40 & 13.5 & 21 \\
\hline Trudan Headless & SxS & $\mathrm{Y}$ & 94.7 & 94.0 & 81.3 & 22.4 & 41 & 11.1 & 43 \\
\hline CHR-SG1 & $\mathrm{Su}$ & $\mathrm{Y}$ & 94.7 & 95.3 & 82.0 & 22.4 & 42 & 12.0 & 36 \\
\hline BMR-90 ${ }^{b}$ & FS & $\mathrm{Y}$ & 99.3 & 94.7 & 98.7 & 22.3 & 43 & 16.1 & 6 \\
\hline Green Treat Plus & SxS & $\mathrm{Y}$ & 92.0 & 87.3 & 74.7 & 22.3 & 44 & 12.7 & 27 \\
\hline XAL 53 & SxS & $\mathrm{N}$ & 91.3 & 84.7 & 61.3 & 22.3 & 45 & 10.4 & 48 \\
\hline SD-1741 & SxS & $\mathrm{Y}$ & 98.7 & 95.3 & 97.3 & 22.2 & 46 & 14.4 & 18 \\
\hline Topper & SW & $\mathrm{N}$ & 93.3 & 86.0 & 68.0 & 22.1 & 47 & 7.7 & 55 \\
\hline Sweet Thing BMR & SxS & $\mathrm{Y}$ & 98.7 & 96.7 & 96.7 & 22.0 & 48 & 12.4 & 29 \\
\hline Pampa Verde Pacas & SxS & $\mathrm{Y}$ & 96.7 & 94.7 & 84.0 & 22.0 & 49 & 8.6 & 52 \\
\hline BMR 108 & FS & $\mathrm{Y}$ & 98.7 & 96.7 & 91.3 & 21.3 & 50 & 11.2 & 42 \\
\hline Top 76-6 & SW & $\mathrm{N}$ & 89.3 & 89.3 & 76.7 & 21.3 & 51 & 8.8 & 51 \\
\hline PI 453014 & GS & $\mathrm{N}$ & 87.3 & 82.7 & 63.3 & 20.9 & 52 & $8 . .2$ & 53 \\
\hline SX17 & SxS & $\mathrm{Y}$ & 89.3 & 81.3 & 40.0 & 20.6 & 53 & 5.2 & 65 \\
\hline Nutri Plus & SxS & $\mathrm{N}$ & 83.9 & 84.0 & 50.0 & 20.7 & 54 & 7.2 & 58 \\
\hline 59-09 & FS & $\mathrm{Y}$ & 98.7 & 90.7 & 94.7 & 20.4 & 55 & 14.1 & 20 \\
\hline 56111 & SW & $\mathrm{Y}$ & 94.7 & 89.3 & 84.0 & 20.3 & 56 & 11.6 & 39 \\
\hline Greentreat A+ & SxS & $\mathrm{Y}$ & 92.7 & 94.7 & 80.7 & 20.2 & 57 & 10.0 & 49 \\
\hline Theis & SW & $\mathrm{N}$ & 90.6 & 91.3 & 70.7 & 19.9 & 58 & 6.8 & 60 \\
\hline Sweet Thing & SxS & $\mathrm{Y}$ & 90.7 & 87.3 & 86.7 & 19.8 & 59 & 11.1 & 44 \\
\hline SPX 3903 & FSH & $\mathrm{Y}$ & 90.7 & 86.6 & 88.7 & 19.5 & 60 & 14.8 & 15 \\
\hline RTx430 & GS & $\mathrm{N}$ & 90.7 & 84.0 & 56.7 & 19.1 & 61 & 7.6 & 56 \\
\hline SS M81-E & SW & $\mathrm{N}$ & 93.3 & 91.2 & 26.0 & 18.5 & 62 & 2.5 & 70 \\
\hline PI 452841 & GS & $\mathrm{N}$ & 86.7 & 76.7 & 49.3 & 18.4 & 63 & 7.4 & 57 \\
\hline Piper (1) & $\mathrm{Su}$ & $\mathrm{N}$ & 92.7 & 90.0 & 52.0 & 16.2 & 64 & 4.5 & 67 \\
\hline Dale & SW & $\mathrm{N}$ & 94.0 & 96.0 & 64.0 & 16.0 & 65 & 5.7 & 63 \\
\hline Special Effort & SxS & $\mathrm{N}$ & 71.7 & 63.3 & 30.7 & 15.2 & 66 & 3.8 & 69 \\
\hline Pacesetter BMR & FS & $\mathrm{Y}$ & 94.7 & 92.0 & 87.3 & 14.6 & 67 & 12.0 & 35 \\
\hline FS-5 & FS & $\mathrm{Y}$ & 90.0 & 81.3 & 42.0 & 14.6 & 68 & 4.3 & 68 \\
\hline Piper (2) & $\mathrm{Su}$ & $\mathrm{Y}$ & 98.0 & 92.7 & 60.0 & 14.0 & 69 & 4.9 & 66 \\
\hline Enorma & $\mathrm{Su}$ & $\mathrm{N}$ & 92.6 & 71.3 & 72.0 & 11.0 & 70 & 6.3 & 62 \\
\hline Forage King ${ }^{a b}$ & $\mathrm{Su}$ & $\mathrm{N}$ & 52.0 & 32.7 & 6.7 & 5.2 & 71 & 0.8 & 71 \\
\hline LSD (0.05) & & & 6.3 & 8.1 & 11.5 & 3.5 & & 2.6 & \\
\hline
\end{tabular}

FS = forage sorghum, FSH = forage sorghum hybrid, $\mathrm{Su}=$ sudangrass, $\mathrm{SxS}=$ sorghum $\times$ sudangrass, $\mathrm{SW}=$ sweet sorghum, GS = grain sorghum, BMR = brown-midrib. ${ }^{\mathrm{a}}$ Selected for field experiment in 2017, ${ }^{\mathrm{b}}$ Selected for field experiment in 2018, ${ }^{\text {ab }}$ Selected for field experiment in both 2017 and 2018. + Values in bold in the table indicate the range of values not significantly different from the highest ranked value within a same column.

\subsection{Seeding Date Study in Field Conditions}

Genotypes field emergence index varied significantly. The seeding date main effect and the interaction of genotypes by seeding date were significant for emergence index $(p \leq 0.05)$ (Figure $3 a)$. Emergence index was much greater for the second seeding date than the first seeding date (Figure 3a), as expected, since soil temperatures were greater at second planting (Figure 2a-d). The genotypes Sordan Headless, NK300, and Hay King emerged faster in the early-seeding date compared with 
the other genotypes. The faster germination and emergence at lower temperatures suggested these genotypes as having better tolerance to chilling temperatures, which was the objective of this study. Despite the lower emergence index of the first seeding date compared with the second seeding date, the first seeding date produced better growth and development as indicated by the greater canopy coverage in all genotypes evaluated (Figure $3 b$ ).

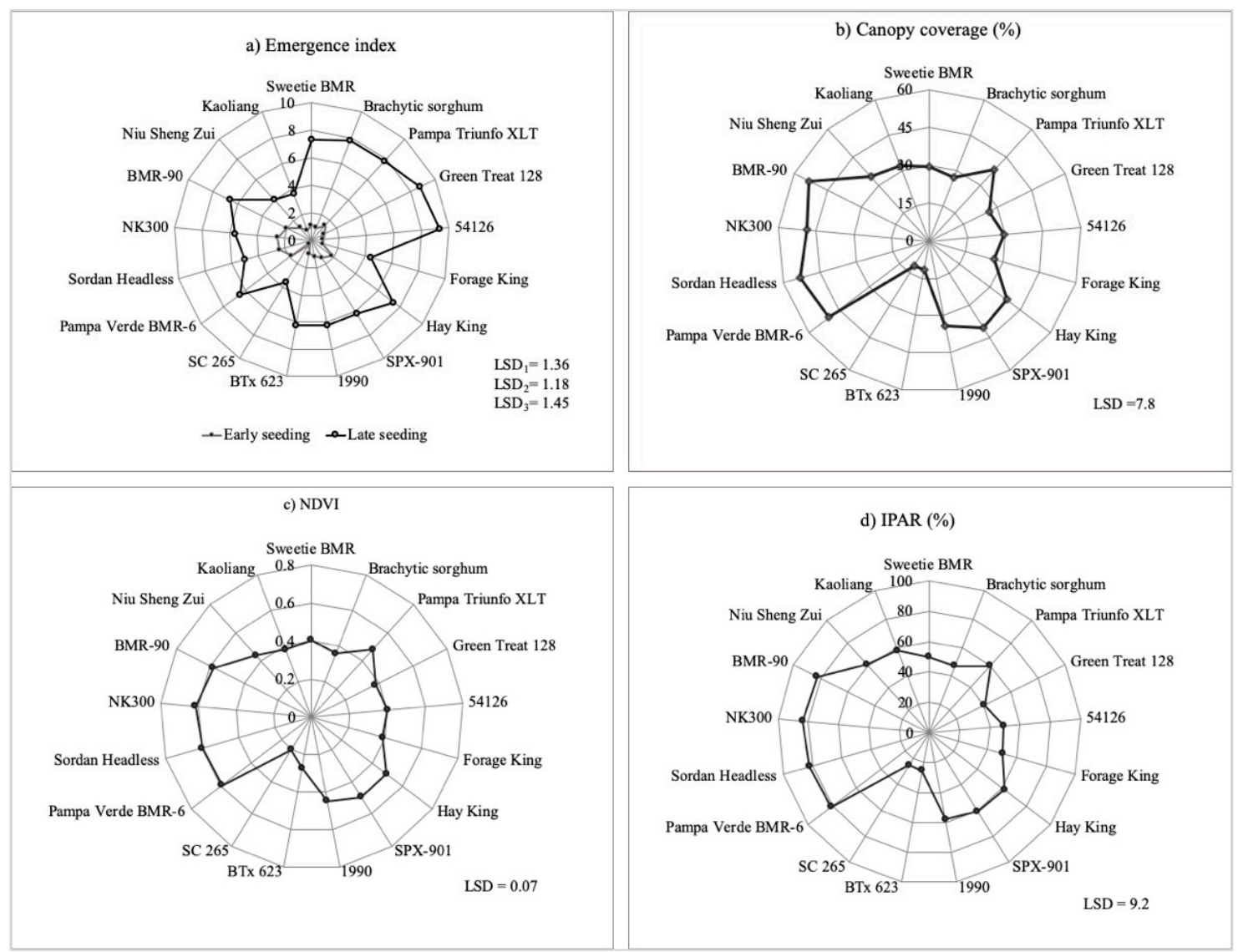

Figure 3. (a) Mean emergence index at early and late seeding, and (b) mean canopy coverage at 46 days after seeding (DAS), (c) mean normalized difference vegetation index (NDVI) evaluated at 49 DAS, (d) mean intercepted photosynthetically active radiation (IPAR) evaluated at 58 DAS in forage sorghum genotypes averaged across two seeding dates and four environments in Fargo and Hickson, ND, USA, in 2017 and 2018. Least significant differences $\left(\mathrm{LSD}_{1}\right)$ to compare among genotypes within the same seeding date, $\mathrm{LSD}_{2}$ to compare same genotype between different seeding date, $\mathrm{LSD}_{3}$ to compare among genotypes on different seeding dates, LSD in Figure $3 \mathrm{~b}-\mathrm{d}$ are to compare among genotypes-mean averaged across seeding date within the same figure.

Temperature below $15{ }^{\circ} \mathrm{C}$ inhibits seedling emergence and decreases emergence rate in forage sorghum $[16,40,41]$. Thus, forage sorghum is typically planted once the average 10-d soil temperature $\left(0-15 \mathrm{~cm}\right.$ in depth) is $>15{ }^{\circ} \mathrm{C}$ [40]. However, significant variation in early-emergence index and emergence percentage has reported previously by Kapanigowda et al. [25], which supports the results in this current study where a lower emergence index was observed with earlier seeding. Thus, field emergence index is an efficient way of screening forage sorghum genotypes for chilling tolerance.

Canopy coverage at 46 days after seeding (DAS) (30 days after the late seeding) was significant for both the seeding date and genotype main effects $(p \leq 0.05)$. No interaction between seeding date and genotype was observed. The genotypes Sordan Headless, Pampa Verde BMR-6, NK300, BMR-90, and SPX-901 had greater canopy coverage at 46 DAS (Figure 3b), indicating those genotypes performed better early season as greater canopy coverage at earlier stages of development indicates rapid growth. 
Chung et al. [42] measured canopy coverage and found a significant correlation between plant height and percentage of green color of four different sorghum genotypes in field conditions. It has been reported that sorghum growth rate is reduced if exposed to temperatures of $<15^{\circ} \mathrm{C}$, especially early in the season $[16,41]$. Therefore, genotypes that grow faster early in the season are potential genetic sources for the chilling tolerance trait.

Under cold stress, a quick reduction in photosynthetic efficiency of forage sorghum seedlings occurs. This is induced by metabolic (non-stomatal) limitation during exposure to suboptimal temperatures and by stomatal limitation after the termination of cold stress [43]. The sorghum plants subjected to cold stress in seedlings stage had lower leaf chlorophyll content and seedling vigor than sorghum seedlings grown without cold stress [27]. Photosynthetic activity of sorghum seedlings decreased under cold stress, indicating measuring photochemical quenching of chlorophyll fluorescence is the efficient way for screening chilling-tolerant sorghum genotypes [44]. Chlorophyll fluorescence was measured on our study, but no differences were observed among genotypes at any date or location, thus the data is not shown.

The genotype main effect was significant at all stages of evaluation for normalized difference vegetation index (NDVI) $(p \leq 0.05)$. A higher NDVI value indicated those genotypes had greater cover and likely were growing faster than the other genotypes seeded earlier, but the genotypes' plant architecture was not homogeneous and likely influenced NDVI. The NDVI differences among genotypes were mainly due to the differences in plant height and coverage (Figure 3c). The possible cause of this may be the genotypes seeded in the second date were younger than the early seeded genotypes at the first harvest. These results indicate NDVI may be better for predicting differences among genotypes cover at the early vegetative stages than later stages of development. Similar results were found by Chiluwal et al. [26] in field conditions using aerial measurement of NDVI. This provides a potentially useful tool to evaluate the phenotypic variation among sorghum genotypes for chilling response at 30 to 60 days after emergence [26].

Seeding date main effect and genotype main effect were significant for intercepted photosynthetically active radiation (IPAR) only at 58 DAS $(p \leq 0.05)$. Before the first harvest, IPAR ranged between $25 \%$ and $84 \%$ at 58 DAS. Sordan Headless, NK300, Pampa Verde BMR-6, and BMR-90 had higher IPAR at 58 DAS than the other genotypes, indicating greater growth and canopy (Figure $3 \mathrm{~d}$ ). Kaoliang and Niu Sheng Zui lines had lower IPAR resulting from reduced tiller number and lower stand establishment compared with other genotypes. After the first harvest, IPAR ranged between 39\% and $81 \%$ at 30 days after harvest (DAH) and $77 \%$ to $95 \%$ at $45 \mathrm{DAH}$ (not shown). In later growing stages, IPAR was similar for all genotypes as ground was covered by tillers regrowth after the first harvest. These results suggest that IPAR predicted differences of genotypes growth at early vegetative stages better than at later growth stages. Maughan et al. [45] found similar results with forage sorghum reaching up to $95 \%$ IPAR in central and southern Illinois, and Meki et al. [46] reported over $90 \%$ IPAR in forage sorghum in a field trial at Temple, TX.

\subsubsection{Seed Mortality}

Mortality of pure live seeds was significant for genotype and the interaction between genotype and seeding date $(p \leq 0.05)$. Higher mortality was observed at the early seeding compared with the late seeding for most genotypes. Sweetie BMR, Pampa Triunfo XLT, Green Treat 128, 54126, Forage King, 1990, SC 265, Niu Sheng Zui, and Kaoliang genotypes had higher mortality percentage at the early seeding compared with the same genotypes seeded later (Figure 4). This indicates that cold soils imposed a stress in seedlings, increasing mortality. Even if mortality was high when seeded early, the ability of the surviving plants to grow once temperatures increased is desired. Though 'Niu Sheng Zui' and 'Kaoliang' are widely known for their chilling tolerance, their seed mortality at the early-seeding date was $45-60 \%$ and not different than many other genotypes on the same seeding date (Figure 4). Seed mortality in cold soils can also be due to pathogens. Soil temperature below $15^{\circ} \mathrm{C}$ promotes susceptibility to molding and other pathogen infections like Pythium spp., P. aphanidermatum, 
P. ultimum, P. arrhenomanes, etc. that ultimately increases the chances for germination failure early in the season [47]. Most of the commercial cultivars and hybrids tested seed had added fungicides. The chilling-tolerant lines-Niu Sheng Zui and Kaoliang were not coated with fungicides (Table 2), which could have stimulated higher seed mortality for those lines. The genotypes NK300 and Sordan Headless had lower seed mortality than most genotypes $(<25 \%)$ at both seeding dates. At early-seeding, seed mortality was not different from that of the late-seeding for these same genotypes. Interestingly, these two genotypes had the highest emergence index and highest stand establishment at early seeding, which is explained by the lower seed mortality. Generally, up to $65-70 \%$ seed emergence may occur during the optimum seeding time, depending on field moisture [40].

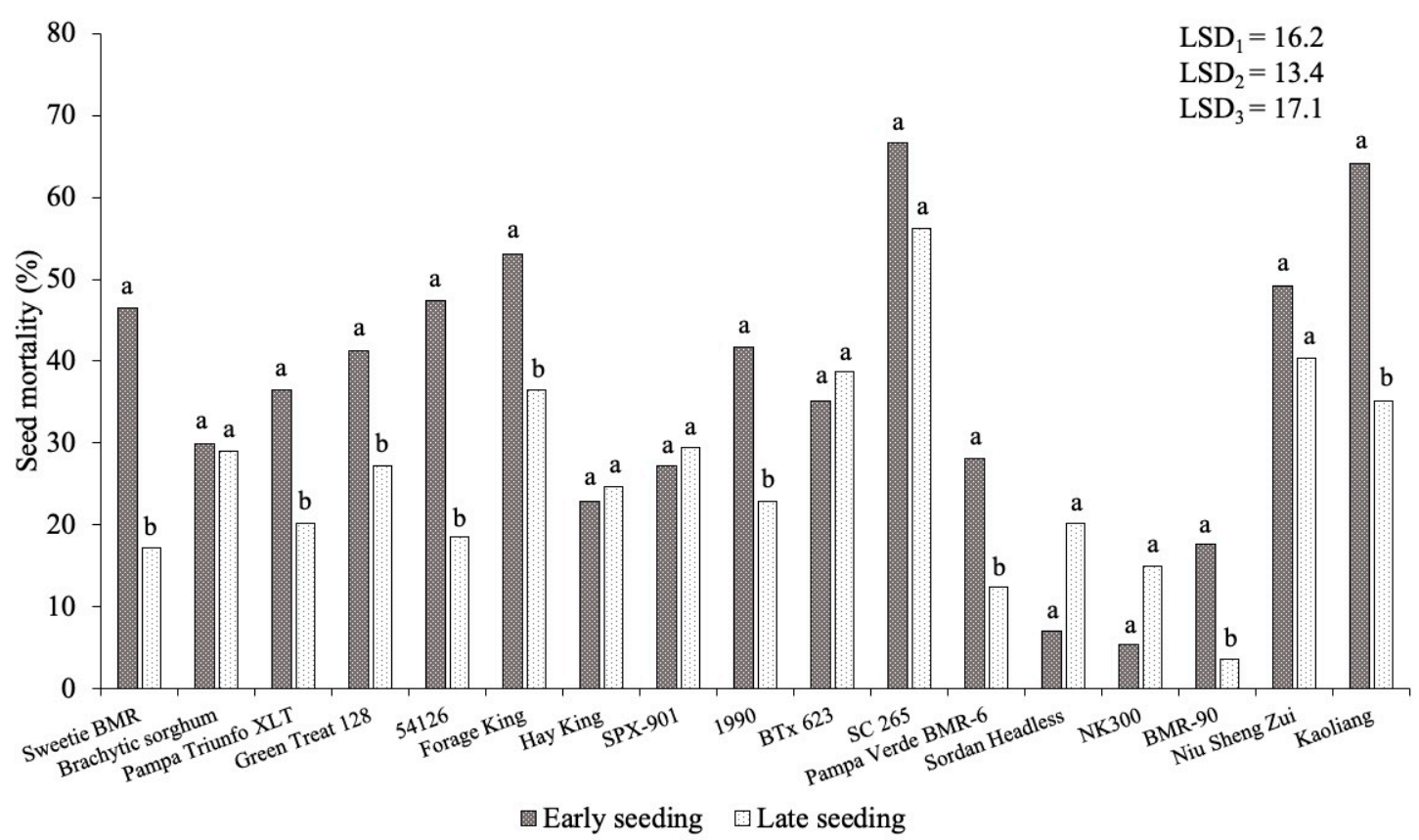

Figure 4. Mean seed mortality rate in forage sorghum genotypes planted on two seeding dates averaged across four environments at 20 days after each planting in Fargo and Hickson, ND, USA, in 2017 and 2018. Least significant differences $\left(\mathrm{LSD}_{1}\right)$ to compare among genotypes within the same seeding date, $\mathrm{LSD}_{2}$ to compare same genotypes between different date and also different small case letters show significant differences, $\mathrm{LSD}_{3}$ to compare among genotypes on different seeding date).

\subsubsection{Plant Height}

Plant height at both harvests was significant among genotypes and seeding dates $(p \leq 0.05)$. However, no interaction was observed for the genotype by seeding date interaction. Plant height was greater for all genotypes in the second harvest than the first harvest (Table 3). Late-seeded genotypes were shorter at first harvest as they had less time to grow compared with early seeded genotypes. After the first harvest, $15 \mathrm{~cm}$ of stalk was left for regrowth. As the plants were already established, it is possible that increased temperatures following the first harvest allowed uptake of more nutrients and water from soil, which allowed the plants to grow taller by the second harvest. However, in this study, nutrient and water uptake were not measured. The genotypes brachytic sorghum, BTx623, and Sc 265 are dwarf types (Table 3). 
Table 3. Mean plant height, biomass yield and dry matter content of two harvests ( $\mathrm{H}-1$ and $\mathrm{H}-2)$ in forage sorghum genotypes seeded on two dates averaged across four environments, in Fargo and Hickson, ND, USA, in 2017 and 2018.

\begin{tabular}{|c|c|c|c|c|c|c|c|}
\hline \multirow{2}{*}{ Genotype } & \multicolumn{2}{|c|}{ Plant Height (m) } & \multicolumn{3}{|c|}{ Biomass Yield (Mg ha-1) } & \multicolumn{2}{|c|}{ Dry Matter (\%) } \\
\hline & H-1 & $\mathrm{H}-2$ & H-1 & $\mathrm{H}-2$ & Total & H-1 & $\mathrm{H}-2$ \\
\hline & \multicolumn{7}{|c|}{ Early Seeding } \\
\hline Sweetie BMR & 1.31 & 1.68 & 3.2 & 8.5 & 11.7 & 17.2 & 22.0 \\
\hline Brachytic sorghum & 0.94 & 1.07 & 3.2 & 8.8 & 12.0 & 18.6 & 23.0 \\
\hline Pampa Triunfo XLT & 1.38 & 1.65 & 3.3 & 9.2 & 12.5 & 16.9 & 23.0 \\
\hline Green Treat 128 & 1.10 & 1.74 & 3.2 & 10.4 & 13.6 & 19.1 & 19.6 \\
\hline 54126 & 1.28 & 1.70 & 3.8 & 12.3 & 16.1 & 17.3 & 20.9 \\
\hline Forage King & 1.64 & 1.95 & 3.1 & 10.4 & 13.4 & 19.0 & 32.9 \\
\hline Hay King & 1.61 & 1.95 & 3.9 & 10.5 & 14.5 & 18.6 & 26.3 \\
\hline SPX-901 & 1.28 & 1.79 & 4.0 & 11.0 & 15.0 & 18.2 & 22.5 \\
\hline 1990 & 1.20 & 1.67 & 4.0 & 10.5 & 14.5 & 18.3 & 21.1 \\
\hline BTх623 & 0.96 & 1.02 & 2.7 & 7.2 & 9.9 & 17.1 & 25.9 \\
\hline SC 265 & 0.72 & 0.87 & 0.7 & 5.6 & 6.3 & 15.5 & 28.3 \\
\hline Pampa Verde BMR-6 & 1.39 & 1.69 & 4.1 & 10.0 & 14.2 & 15.2 & 21.9 \\
\hline Sordan Headless & 1.57 & 1.94 & 5.3 & 12.7 & 18.0 & 16.4 & 22.5 \\
\hline NK300 & 1.41 & 1.45 & 5.6 & 10.3 & 15.9 & 17.7 & 24.1 \\
\hline BMR-90 & 1.64 & 1.73 & 4.6 & 9.7 & 14.4 & 16.6 & 26.2 \\
\hline Niu Sheng Zui & 1.68 & 2.04 & 2.1 & 5.3 & 7.4 & 14.9 & 30.9 \\
\hline \multirow[t]{2}{*}{ Kaoliang } & 1.67 & 2.19 & 1.6 & 7.2 & 8.7 & 16.6 & 36.2 \\
\hline & \multicolumn{7}{|c|}{ Late Seeding } \\
\hline Sweetie BMR & 1.09 & 1.77 & 2.5 & 11.0 & 13.5 & 16.9 & 23.6 \\
\hline Brachytic sorghum & 0.90 & 1.06 & 3.2 & 10.5 & 13.7 & 18.4 & 22.8 \\
\hline Pampa Triunfo XLT & 1.17 & 1.74 & 2.6 & 10.6 & 13.2 & 16.7 & 23.4 \\
\hline Green Treat 128 & 1.07 & 1.76 & 3.1 & 13.1 & 16.2 & 19.4 & 20.5 \\
\hline 54126 & 1.25 & 1.74 & 3.6 & 14.0 & 17.6 & 17.8 & 21.5 \\
\hline Forage King & 1.37 & 1.98 & 2.2 & 11.1 & 13.3 & 17.6 & 30.1 \\
\hline Hay King & 1.43 & 1.98 & 2.9 & 11.6 & 14.5 & 17.5 & 26.4 \\
\hline SPX-901 & 1.02 & 1.97 & 2.9 & 13.1 & 16.0 & 18.4 & 22.7 \\
\hline 1990 & 0.97 & 1.89 & 2.7 & 13.0 & 15.7 & 17.9 & 21.7 \\
\hline BTх623 & 0.89 & 1.10 & 1.3 & 5.1 & 6.4 & 17.0 & 25.8 \\
\hline SC 265 & 0.71 & 0.85 & 1.1 & 5.9 & 7.0 & 15.9 & 27.5 \\
\hline Pampa Verde BMR-6 & 1.03 & 1.87 & 2.5 & 12.3 & 14.8 & 15.3 & 20.1 \\
\hline Sordan Headless & 1.14 & 2.11 & 2.6 & 13.3 & 15.9 & 15.0 & 20.4 \\
\hline NK300 & 1.05 & 1.63 & 3.2 & 12.5 & 15.6 & 16.4 & 25.6 \\
\hline BMR-90 & 1.26 & 1.94 & 3.0 & 13.9 & 17.0 & 14.6 & 28.3 \\
\hline Niu Sheng Zui & 1.21 & 2.27 & 1.2 & 5.8 & 7.0 & 13.5 & 31.9 \\
\hline Kaoliang & 1.21 & 2.37 & 1.1 & 6.3 & 7.3 & 14.3 & 31.6 \\
\hline $\mathrm{LSD}_{1}(0.05)$ & 0.11 & 0.16 & 0.6 & 2.2 & 2.4 & 1.5 & 2.3 \\
\hline $\mathrm{LSD}_{2}(0.05)$ & & & 0.5 & 1.2 & 1.4 & & \\
\hline
\end{tabular}

Least significant differences $\left(\mathrm{LSD}_{1}\right)$ to compare genotypes within the same or different seeding date, $\mathrm{LSD}_{2}$ to compare same genotypes within different seeding date within each harvest date. 


\subsubsection{Biomass Yield}

Genotype and seeding date main effects and their interaction were significant for biomass yield at each harvest. The interaction between genotypes and seeding dates occurred because genotypes had a different response to early seeding (Table 3). The genotypes Sweetie BMR, Brachytic Sorghum, 54126, Green Treat 128, and BMR 90 produced less biomass yield in the early-seeding dates compared with late-seeding dates, which indicated that those genotypes were affected negatively by the conditions early in the season. The genotypes Pampa Triunfo XLT, Forage King, Hay King, SPX-901, 1990, SC 265, Pampa Verde BMR-6, NK300, and Niu Shen Zui biomass yield was the same for both seeding dates. The genotypes Sordan Headless, BTx623, and Kaoliang had greater biomass yield in early seeding dates compared with late-seeding dates. However, genotypes BTx623 and Kaoliang had less seasonal biomass yield than all other genotypes as those are grain type sorghums with less tillering capacity. The genotype Sordan Headless had greater biomass yield $\left(18 \mathrm{Mg} \mathrm{ha}^{-1}\right)$ in the early seeding date than all other genotypes (Table 3 ). The increased biomass observed for early seeding dates identified the genotype Sordan Headless as able to grow in colder soils, which was the objective of this study.

\subsubsection{Dry Matter Content}

The genotype main effect was significant for dry matter content at each harvest, while an interaction between genotype and seeding date was observed only for the second harvest. Seeding date main effect was not significant for dry matter content. Kaoliang, Niu Shen Zui, and Forage King had higher dry matter content for both seeding dates in the second harvest (Table 3), which indicated that those genotypes were in more advanced growth stages than the other genotypes. The dry matter content is important if forage sorghum silage will be used for biogas production. Forage sorghum genotypes with greater dry matter at harvest have increased starch and sugar content and that will increase methane yield during anaerobic digestion [48]. This is very important if forage sorghum is produced as feedstock for bioenergy, whether it is for anaerobic digestion or lignocellulosic biochemical conversion [1]. Breeding programs in energy sorghum select genotypes with high biomass productivity, low lignin content, adaptability to low temperature, drought tolerance, high water use efficiency, photosensitivity for increasing cycle duration, higher dry matter content, lower leaf to stem ratio in the fall before frost, and high soluble solids concentration (measured by Brix) in the stem and juice yield in sweet sorghum [49]. Forage sorghum harvested with high moisture content $(>70 \%)$ promotes seepage in the silo leading to nutrient losses, lower digestibility, and production of butyric acid as wet silage promotes higher fermentation losses and lower intake by cows [40].

\subsection{Biomass Yield Prediction}

Emergence index was a good predictor of biomass yield of the first harvest for both seeding dates (early-seeding, $r^{2}=0.74$ (Figure 5a); late-seeding, $r^{2}=0.60$ (Figure 5b), indicating earlier emerging genotypes have greater vigor and better biomass yield at first harvest. Similarly, NDVI at 49 DAS $\left(r^{2}=0.67\right)$ (Figure 5c) and $20 \mathrm{DAH}\left(r^{2}=0.61\right)$ (Figure $5 \mathrm{~d}$ ) were good predictors of biomass yield of the first and second harvest, respectively. Tagarakis et al. [50] found the best prediction of biomass yield of forage sorghum by NDVI at 49 days after planting when plants were $0.76 \mathrm{~m}$ tall. Foster et al. [51] reported a strong correlation $(r=0.72)$ between narrow-band NDVI and biomass yield of sorghum measured on June to July in 2012 and 2013 in Oklahoma. 

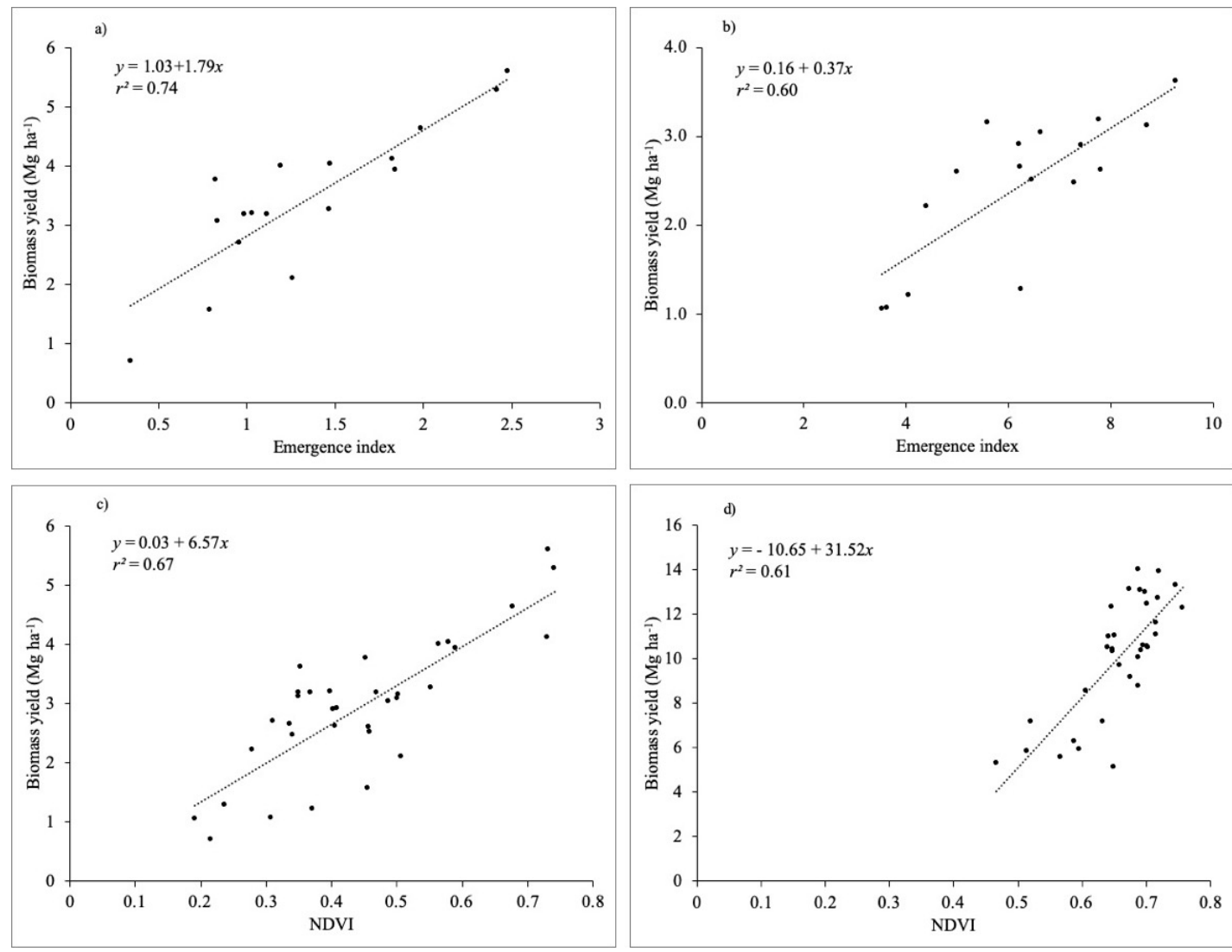

Figure 5. (a) Emergence index vs. biomass yield for early-seeding at first harvest, (b) emergence index vs. biomass yield for late-seeding at first harvest, (c) normalized difference vegetation index (NDVI) at 49 days after seeding (DAS) vs. biomass yield for first harvest, and (d) NDVI at 20 days after harvest (DAH) vs. biomass yield for second harvest in forage sorghum genotypes $(G)$ averaged across four environments, Fargo and Hickson, ND, USA, in 2017 and 2018.

\subsection{Forage Nutritive Value}

Crude protein $(\mathrm{CP})$ content varied among genotypes and harvest dates but not between seeding dates $(p \leq 0.05)$. Crude protein content was much greater in the first harvest, which was expected because of the higher leaf-to-stem ratio at harvest and that most plants were still in vegetative stage (Table 4). Plants were harvested when the first genotypes, in either seeding date, reached $1.4 \mathrm{~m}$ tall. This is the recommended harvest date for high quality hay and for grazing because of the high nutritive value of the forage at this stage [1]. Genotypes with higher CP values were those shortest at harvest. Crude protein in the second harvest was about half of that of the first harvest for all genotypes, since plants had lower leaf-to-stem ratios and plants were in more advanced growth stages. In the first harvest, greater $\mathrm{CP}$ values were observed among the late-seeded genotypes, as those were younger in stage at harvest compared with early-seeded genotypes (Table 4). The range of CP was 133-214 g $\mathrm{kg}^{-1}$ in the first harvest and $63-106 \mathrm{~g} \mathrm{~kg}^{-1}$ in the second harvest (Table 4). Crude protein requirement in mature beef cattle ranges between $70-90 \mathrm{~g} \mathrm{~kg}^{-1}$; thus, in both harvests, most sorghum genotypes meet this requirement [52]. In the first harvest, the highest CP values were observed in SC 265 and in BTx623, as those are grain-type genotypes and are shortest in height (Table 4). Pampa Verde BMR-6 had the highest $\mathrm{CP}$ content in the second harvest (Table 4), although not different from NK300, BMR 90, BTx623, SC 265, and Niu Sheng Zui. In the two-cut system, forage sorghum produced high -quality forage in the first harvest, which can be utilized for beef cattle; with the low-quality, high-biomass yield in the second harvest utilized for bioenergy production. Samarappuli and Berti [1] reported 104-105 $\mathrm{g} \mathrm{kg}^{-1} \mathrm{CP}$ in a single-harvest for bioenergy production in September of non-brown mid rib (BMR) and BMR forage sorghum in North Dakota. 
Table 4. Mean value of biomass quality in forage sorghum genotypes in the first and second harvest averaged across two seeding dates and four environments, Fargo and Hickson, ND, USA, in 2017 and 2018.

\begin{tabular}{|c|c|c|c|c|c|c|c|}
\hline & $\mathrm{CP}$ & Nacc & $\mathbf{N}$ & ADL & $\mathrm{ADF}$ & NDF & Ash \\
\hline Genotypes & $\mathrm{g} \mathrm{kg}^{-1}$ & kg ha $^{-1}$ & & & $\mathrm{~g} \mathrm{~kg}^{-1}$ & & \\
\hline & \multicolumn{7}{|c|}{ First Harvest } \\
\hline Sweetie BMR & 172 & 75.8 & 28 & 29 & 279 & 543 & 130 \\
\hline Brachytic sorghum & 169 & 86.2 & 27 & 32 & 278 & 552 & 102 \\
\hline Pampa Triunfo XLT & 170 & 78.6 & 27 & 32 & 279 & 549 & 133 \\
\hline Green Treat 128 & 168 & 84.7 & 27 & 29 & 285 & 543 & 99 \\
\hline 54126 & 162 & 94.5 & 26 & 34 & 278 & 543 & 110 \\
\hline Forage King & 183 & 73.4 & 29 & 36 & 277 & 546 & 118 \\
\hline Hay King & 166 & 87.7 & 27 & 32 & 279 & 541 & 121 \\
\hline SPX-901 & 162 & 88.7 & 26 & 35 & 288 & 562 & 127 \\
\hline 1990 & 166 & 86.2 & 27 & 34 & 290 & 570 & 124 \\
\hline BTx623 & 208 & 63.2 & 33 & 35 & 272 & 532 & 106 \\
\hline SC 265 & 209 & 29.2 & 33 & 34 & 272 & 541 & 112 \\
\hline Pampa Verde BMR-6 & 174 & 88.0 & 28 & 33 & 285 & 552 & 165 \\
\hline Sordan Headless & 159 & 95.2 & 25 & 35 & 288 & 560 & 158 \\
\hline NK300 & 146 & 99.0 & 23 & 35 & 289 & 571 & 146 \\
\hline BMR-90 & 161 & 96.5 & 26 & 32 & 281 & 554 & 151 \\
\hline Niu Sheng Zui & 170 & 40.1 & 27 & 32 & 289 & 564 & 143 \\
\hline Kaoliang & 155 & 29.0 & 25 & 34 & 292 & 567 & 141 \\
\hline \multirow[t]{2}{*}{$\mathrm{LSD}_{1}(0.05)$} & 13 & 16.5 & 2 & 3 & 9 & 15 & 14 \\
\hline & \multicolumn{7}{|c|}{ Second Harvest } \\
\hline Sweetie BMR & 79 & 119 & 13 & 28 & 309 & 585 & 91 \\
\hline Brachytic sorghum & 86 & 133 & 14 & 26 & 311 & 585 & 83 \\
\hline Pampa Triunfo XLT & 87 & 138 & 14 & 33 & 303 & 587 & 94 \\
\hline Green Treat 128 & 69 & 121 & 11 & 17 & 328 & 591 & 83 \\
\hline 54126 & 66 & 139 & 11 & 32 & 301 & 551 & 76 \\
\hline Forage King & 69 & 117 & 11 & 46 & 344 & 641 & 80 \\
\hline Hay King & 71 & 120 & 11 & 36 & 329 & 615 & 82 \\
\hline SPX-901 & 81 & 148 & 13 & 38 & 330 & 623 & 91 \\
\hline 1990 & 89 & 162 & 14 & 35 & 322 & 617 & 97 \\
\hline BTx623 & 91 & 83 & 15 & 36 & 313 & 580 & 102 \\
\hline SC 265 & 98 & 87 & 16 & 33 & 302 & 580 & 95 \\
\hline Pampa Verde BMR-6 & 104 & 186 & 17 & 38 & 285 & 569 & 127 \\
\hline Sordan Headless & 88 & 183 & 14 & 46 & 302 & 596 & 115 \\
\hline NK300 & 93 & 169 & 15 & 47 & 296 & 607 & 96 \\
\hline BMR-90 & 94 & 178 & 15 & 42 & 294 & 587 & 106 \\
\hline Niu Sheng Zui & 96 & 83 & 15 & 52 & 325 & 630 & 102 \\
\hline Kaoliang & 84 & 85 & 13 & 54 & 339 & 645 & 99 \\
\hline $\mathrm{LSD}_{2}(0.05)$ & 15 & 35 & 2 & 5 & 18 & 25 & 14 \\
\hline
\end{tabular}

Crude protein $(\mathrm{CP})$, nitrogen accumulated in biomass (Nacc), nitrogen $(\mathrm{N})$, acid detergent lignin (ADL), acid detergent fiber (ADF), neutral detergent fiber (NDF); Least significant differences $\left(\mathrm{LSD}_{1}\right)$ to compare genotypes within the first harvest, $\mathrm{LSD}_{2}$ to compare same genotypes within the second harvest. 
Nitrogen $(\mathrm{N})$ accumulation averaged across genotypes was much greater in the second harvest. Biomass yield in the second harvest was three to four times higher than the first harvest, hence the greater $\mathrm{N}$ accumulation. Among the early seeded genotypes, Sordan Headless and NK300 had the highest nitrogen accumulation with both harvests summed compared with the other genotypes (Table 4). Samarappuli and Berti [1] observed the highest nitrogen accumulation in non-BMR forage sorghum genotypes in North Dakota, which is similar with the current study. Anfinrud et al. [4] reported average nitrogen uptake by forage sorghum with a single harvest, ranging between 50 to $150 \mathrm{~kg} \mathrm{~N} \mathrm{ha}^{-1}$ depending on nitrogen fertility level at Fargo and Prosper, ND. In the current study, nitrogen accumulation was much higher than Anfinrud et al. [4] reported; however, only if the second harvest (one-cut system) is taken into account was $\mathrm{N}$ accumulation similar. Forage sorghum is known as an efficient soil nitrogen scavenger, especially where nitrogen accumulation depends on multiple factors such as sorghum types and hybrids, stage of harvest, and availability of nitrogen in soil [53]. Pedersen et al. [53] found nitrogen accumulation ranged between $137 \mathrm{~kg} \mathrm{~N} \mathrm{ha}^{-1}$ and $283 \mathrm{~kg} \mathrm{~N} \mathrm{ha}^{-1}$ in 18 genotypes of six different types of sorghum. In the current study, with a two-cut system, $\mathrm{N}$ concentration in biomass was greater at first harvest $\left(23-33 \mathrm{~g} \mathrm{~kg}^{-1}\right)$ compared with the second harvest (11-17 $\left.\mathrm{g} \mathrm{kg}^{-1}\right)$.

Total accumulated nitrogen exceeded the sum of $\mathrm{N}$-fertilizer input and soil nitrogen at $60 \mathrm{~cm}$. It was assumed that the excess nitrogen could be from the mineralized nitrogen during the season, since these soils are high in organic matter $\left(50-60 \mathrm{~g} \mathrm{~kg}^{-1}\right)$. Mineralization is a process of decomposing organic nitrogen from crops residues, to ammonium. Mineralization depends on soil temperature $\left(20\right.$ to $\left.35^{\circ} \mathrm{C}\right)$, soil water, and oxygen availability in the soil [54]. It is estimated that around 67 to $90 \mathrm{~kg} \mathrm{~N} \mathrm{ha}^{-1}$ is mineralized from organic soil in each year in a study conducted in New York, USA [54]. Kaur et al. [55] conducted an eight-week incubation study from $0 \mathrm{~cm}$ to $15 \mathrm{~cm}$ in depth of soil and found cumulative nitrogen mineralized ranged between $0.34 \mathrm{~N} \mathrm{~kg}^{-1}$ and $2.15 \mathrm{mg} \mathrm{N} \mathrm{kg}^{-1}$ for the Glyndon soils and $0.45 \mathrm{~N} \mathrm{~kg}^{-1}$ to $3.41 \mathrm{mg} \mathrm{kg}^{-1}$ for the Fargo soils, respectively.

Low lignin content is a desired character for high nutritive value forage. Brown mid-rib (BMR) genotypes had lower lignin content than non-BMR sorghum, as expected. In the first harvest, the range of acid detergent lignin (ADL) content was $29-36 \mathrm{~g} \mathrm{~kg}^{-1}$ and in the second harvest ADL was $17-54 \mathrm{~g} \mathrm{~kg}^{-1}$. In the first harvest, lignin content was higher among the early-seeded non-BMR genotypes such as Forage King, Sordan Headless, NK300, and Kaoliang (Table 4). Low lignin content was observed in each harvest among the BMR genotypes like Sweetie BMR, Green Treat 128, Brachytic, Pampa Triunfo XLT, and BMR 90 (Table 4). Lee et al. [56] reported $80 \mathrm{~g} \mathrm{~kg}^{-1} \mathrm{ADL}$ in non-BMR forage sorghum evaluated in South Dakota. Samarappuli and Berti [1] observed $58 \mathrm{~g} \mathrm{~kg}^{-1}$ and $68 \mathrm{~g} \mathrm{~kg}^{-1}$ ADL in a BMR forage sorghum and non-BMR forage sorghum, respectively, in Fargo, Prosper, and Carrington, ND, USA. Lignin content increases with the progressing plant maturity. In the current study, most of the genotypes were in vegetative stage at first harvest and in early reproductive stage at second harvest, which explains the ADL content observed.

Genotypes main effect was significant for neutral detergent fiber (NDF) and acid detergent fiber (ADF) in both harvests where seeding date main effect was significant for ADF and NDF in the first harvest only. Among the genotypes, the range of ADF was $265-304 \mathrm{~g} \mathrm{~kg}^{-1}$ and $284-348 \mathrm{~g} \mathrm{~kg}^{-1}$ in the first and second harvest respectively (Table 4). The range of NDF was 525-579 g kg-1 and 546-652 $\mathrm{g} \mathrm{kg}^{-1}$ in the first and second harvest, respectively (Table 4). Samarappuli and Berti [1] reported 304-331 $\mathrm{g} \mathrm{kg}^{-1} \mathrm{ADF}$ and $542-572 \mathrm{~g} \mathrm{~kg}^{-1} \mathrm{NDF}$ in two forage sorghum genotypes in North Dakota. Anfinrud et al. [4] reported 251-366 g kg-1 ADF and 518-634 $\mathrm{g} \mathrm{kg}^{-1} \mathrm{NDF}$ in forage sweet sorghum and sorghum $\times$ sudangrass in North Dakota, which are similar to the ranges observed in our study. The NDF consists of all the fibers (hemicellulose, cellulose, and lignin) in the plant cell walls and only a fraction of NDF is partially digestible. In a feed ration calculation, NDF is considered to determine the total feed intake. The NDF increases with plant maturity and with the increase of NDF feed intake decreases. The ADF is partially digestible and consists of cellulose and lignin. Digestion of forage decreases as ADF increases. Low NDF and low ADF are desired for high nutritive value 
forage. Prime quality forage for beef cattle consists of $<400 \mathrm{~g} \mathrm{~kg}^{-1} \mathrm{NDF}$ and $<310 \mathrm{~g} \mathrm{~kg}^{-1}$ ADF [57]. Effective fiber expressed as eNDF is necessary to maintain the rumen function and $\mathrm{pH}$ level in optimum condition [57]. Depending on feeding management, up to $250 \mathrm{~g} \mathrm{~kg}^{-1} \mathrm{eNDF}$ is needed for beef cattle to maintain the optimum $\mathrm{pH}(>5.7)$ level for maximum digestion and microbial growth [57]. In our study, the ADF was within the desired range while NDF value was higher than prime quality forages. It was indicated that the lignin content was lower, which mean higher digestible forages.

Genotypes main effect was significant for ash content at first harvest and second harvest. The range of ash content was $99-165 \mathrm{~g} \mathrm{~kg}^{-1}$ at first harvest and $76-127 \mathrm{~g} \mathrm{~kg}^{-1}$ at second harvest (Table 4). Ash content was lower at second harvest compared with first harvest. The ash content was greater than that reported by Samarappuli and Berti [1] (63-65 $\left.\mathrm{g} \mathrm{kg}^{-1}\right)$. Mahmood et al. [48] stated that ash content in biomass was affected by cultivar and by site with a range of $61-98 \mathrm{~g} \mathrm{~kg}^{-1}$. Ash content in the biomass varies with soil type and harvesting process [58]. Ash is considered as waste byproduct and an anti-quality factor in biomass conversion to energy. Biogas production from biomass is negatively affected by high ash content as microorganisms cannot decompose the ash [1], while in thermochemical conversion systems, biomass cannot be heated above $400^{\circ} \mathrm{C}$; otherwise, the ash melts and clogs the reactor [59]. That is a reason a lower ash content is desired in bioenergy feedstocks.

\section{Conclusions}

Forage sorghum had lower germination percentages and slower germination rates at $10{ }^{\circ} \mathrm{C}$ compared with $12^{\circ} \mathrm{C}$ and $24^{\circ} \mathrm{C}$. Early in the season, forage sorghum was affected by cold soil conditions, which reduced the emergence index, and increased seed mortality. Earlier and fast-emerging genotypes had better growth performance and produced greater biomass yield at earlier planting in the field. Emergence index, and normalized difference vegetation index had better prediction of biomass yield. Commercial forage sorghum cultivars-Sordan Headless, NK300, Hay King, and SPX-901—have the potential to grow early in the season. These genotypes can be evaluated in breeding programs for introgression of the early-season chilling-tolerant trait into high biomass producing forage sorghum. Chemical components of forage sorghum were not affected by seeding date. Nutritive value depended on harvesting stages of forage sorghum. Forage sorghum with a two-cut system can be utilized to get better quality forage without reducing biomass yield. Commercial forage sorghum cultivars-Hay King, Forage King, NK300, and BMR-90 — can be potential feedstocks for bioenergy. From this study, commercially available chilling-tolerant forage sorghum genotypes were identified, which should enhance the acreage and production of forage sorghum biomass and increase diversification of cropping systems in the north central region (NCR) of the USA.

Author Contributions: Conceptualization, M.T.B.; Formal analysis, S.P. and M.T.B.; Funding acquisition, M.T.B.; Investigation, S.P., D.S., and M.T.B.; Methodology, S.P. and D.S.; Project administration, M.T.B.; Resources, J.V.A. and M.T.B.; Supervision, M.T.B.; Writing—original draft, S.P.; Writing—review and editing, S.P., D.S., J.V.A., and M.T.B., S.P. conducted experiments, analyzed data, made tables and figures, wrote the first manuscript draft, and edited it further. D.S. collaborated on the execution of experiments and editing and formatting of manuscript. J.A. collaborated on research idea, experimental design, providing growth chamber facilities, and manuscript editing. M.T.B. proposed the research idea, obtained the funding for the research, designed experiments, assisted with statistical analysis, and wrote the final manuscript. All authors have read and agreed to the published version of the manuscript.

Funding: This research was funded in part by the North Central SunGrant Initiative NIFA-USDA, award number 3TL640; the North Dakota State University Agricultural Experimental Station project ND 01586; NC-SARE project ENC 18-165; and the USDA-ARS CRIS project 3060-21220-029-00D.

Acknowledgments: Authors also wish to thank all technical staff, undergraduate, and graduate students that helped support these studies.

Conflicts of Interest: The authors declare no conflict of interest. 


\section{References}

1. Samarappuli, D.; Berti, M.T. Intercropping forage sorghum with maize is a promising alternative to maize silage for biogas production. J. Clean. Prod. 2018, 194, 515-524. [CrossRef]

2. Berti, M.T.; Nudell, R.; Anfinrud, R.; Samarappuli, D.; Johnson, B.L. Forage resources as feedstocks for the biofuel industry in North Dakota. In Proceedings of the European Biomass Conference, Berlin, Germany, 6-9 June 2011. Available online: https://www.ag.ndsu.edu/plantsciences/research/forages/docs/ ForageResourcesAsFeedstocksForBiofuel.pdf (accessed on 20 May 2020).

3. Samarappuli, D.P.; Johnson, B.L.; Kandel, H.; Berti, M.T. Biomass yield and nitrogen content of annual energy/forage crops preceded by cover crops. Field Crops Res. 2014, 167, 31-39. [CrossRef]

4. Anfinrud, R.; Cihacek, L.; Johnson, B.L.; Ji, Y.; Berti, M.T. Sorghum and kenaf biomass yield and quality response to nitrogen fertilization in the northern Great Plains of the USA. Ind. Crops Prod. 2013, 50, $159-165$. [CrossRef]

5. Rooney, W.L.; Blumenthal, J.; Bean, B.; Mullet, J.E. Designing sorghum as a dedicated bioenergy feedstock. Biofuels Bioprod. Biorefining 2007, 1, 147-157. [CrossRef]

6. Howell, T.A.; Evett, S.R.; Tolk, J.A.; Copeland, K.S.; Colaizzi, P.D.; Gowda, P.H. Evapotranspiration of corn and forage sorghum for silage. In Proceedings of the World Environmental and Water Resources Congress, Ahupua'a, Honolulu, HI, USA, 12-16 May 2008; ASCE: Reston, VA, USA.

7. McCollum III, T.; McCuistion, K.; Bean, B. Brown mid-rib and photoperiod sensitive forage sorghums. In Proceedings of the 2005 Plains Nutrition Council Spring, San Antonio, TX, USA, 14-15 April 2005. Available online: http://agrilife.org/amarillo/files/2010/11/brownmidrib.pdf (accessed on 19 May 2020).

8. Maucieri, C.; Cavallaro, V.; Caruso, C.; Borin, M.; Milani, M.; Barbera, A.C. Sorghum biomass production for energy purpose using treated urban wastewater and different fertilization in a Mediterranean environment. Agriculture 2016, 6, 67. [CrossRef]

9. Ganyo, K.K.; Muller, B.; Ndiaye, M.; Gaglo, E.K.; Guissé, A.; Adam, M. Defining fertilization strategies for sorghum (Sorghum bicolor (L.) Moench) production under Sudano-Sahelian conditions: Options for late basal fertilizer application. Agronomy 2019, 9, 697. [CrossRef]

10. Perazzo, A.F.; Carvalho, G.G.P.; Santos, E.M.; Bezerra, H.F.C.; Silva, T.C.; Pereira, G.A.; Ramos, R.C.S.; Rodrigues, J.A.S. Agronomic evaluation of sorghum hybrids for silage production cultivated in semiarid conditions. Front. Plant Sci. 2017, 8, 8. [CrossRef]

11. Undersander, D.J.; Smith, L.H.; Kaminski, A.R.; Kelling, K.A.; Doll, J.D. Sorghum-forage. In Alternative Field Crops Manual; Department of Agronomy, University of Wisconsin Cooperative or Extension Service: Madison, WI, USA; University of Minnesota Extension Service: St. Paul, MN, USA, 1990. Available online: https://hort.purdue.edu/newcrop/afcm/forage.html (accessed on 19 May 2020).

12. Razmi, Z.; Hamidi, R.; Pirasteh-Anosheh, H. Seed germination and seedling growth of three sorghum (Sorghum bicolor L.) genotypes as affected by low temperatures. Int. J. Farm. Allied Sci. 2013, 20, 851-856.

13. Peacock, J.M. Response and tolerance of sorghum to temperature stress. In Sorghum in the Eighties Proceedings of the International Symposium on Sorghum; House, L.R., Mughogho, L.K., Peacock, J.M., Mertin, J.V., Eds.; ICRISAT Center: Patancheru, India, 1981.

14. Patane, C.; Cavallaro, V.; Avola, G.; D'Agosta, G. Seed respiration of sorghum Sorghum bicolor (L.) Moench during germination as affected by temperature and osmoconditioning. Seed Sci. Res. 2006, 16, 251-260. [CrossRef]

15. Yu, J.; Tuinstra, M.R.; Claassen, M.M.; Gordon, W.B.; Witt, M.D. Analysis of cold tolerance in sorghum under controlled environment conditions. Field Crops Res. 2004, 85, 21-30. [CrossRef]

16. Singh, S.P. Sources of cold tolerance in grain-sorghum. Can. J. Plant Sci. 1985, 65, 251-257. [CrossRef]

17. Marla, S.R.; Shiva, S.; Welti, R.; Liu, S.Z.; Burke, J.J.; Morris, G.P. Comparative transcriptome and lipidome analyses reveal molecular chilling responses in chilling-tolerant sorghums. Plant Genome 2017, 10, 16. [CrossRef] [PubMed]

18. Maulana, F.; Weerasooriya, D.; Tesso, T. Sorghum landrace collections from cooler regions of the world exhibit magnificent genetic differentiation and early season cold tolerance. Front. Plant Sci. 2017, 8, 756. [CrossRef] [PubMed]

19. Knoll, J.; Gunaratna, N.; Ejeta, G. QTL analysis of early-season cold tolerance in sorghum. Theor. Appl. Genet. 2008, 116, 577-587. [CrossRef] [PubMed] 
20. Fiedler, K.; Bekele, W.A.; Duensing, R.; Gruendig, S.; Snowdon, R.; Stuetzel, H.; Zacharias, A.; Uptmoor, R. Genetic dissection of temperature-dependent sorghum growth during juvenile development. Theor. Appl. Genet. 2014, 127, 1935-1948. [CrossRef]

21. Bekele, W.A.; Fiedler, K.; Shiringani, A.; Schnaubelt, D.; Windpassinger, S.; Uptmoor, R.; Friedt, W.; Snowdon, R.J. Unravelling the genetic complexity of sorghum seedling development under low-temperature conditions. Plant Cell Environ. 2014, 37, 707-723. [CrossRef]

22. Franks, C.D.; Burow, G.B.; Burke, J.J. A comparison of US and Chinese sorghum germplasm for early season cold tolerance. Crop Sci. 2006, 46, 1371-1376. [CrossRef]

23. Fernandez, M.G.S.; Schoenbaum, G.R.; Goggi, A.S. Novel germplasm and screening methods for early cold tolerance in sorghum. Crop Sci. 2014, 54, 2631-2638. [CrossRef]

24. Tiryaki, I.; Andrews, D.J. Germination and seedling cold tolerance in sorghum: I. Evaluation of rapid screening methods. Agron. J. 2001, 93, 1386-1391. [CrossRef]

25. Kapanigowda, M.H.; Perumal, R.; Aiken, R.M.; Herald, T.J.; Bean, S.R.; Little, C.R. Analyses of sorghum Sorghum bicolor (L.) Moench lines and hybrids in response to early-season planting and cool conditions. Can. J. Plant Sci. 2013, 93, 773-784. [CrossRef]

26. Chiluwal, A.; Bheemanahalli, R.; Perumal, R.; Asebedo, A.R.; Bashir, E.; Lamsal, A.; Sebela, D.; Shetty, N.J.; Jagadish, S.V.K. Integrated aerial and destructive phenotyping differentiates chilling stress tolerance during early seedling growth in sorghum. Field Crops Res. 2018, 227, 1-10. [CrossRef]

27. Maulana, F.; Tesso, T.T. Cold temperature episode at seedling and flowering stages reduces growth and yield components in sorghum. Crop Sci. 2013, 53, 564-574. [CrossRef]

28. Web Soil Survey. National Resources Conservation Service; United States Department of Agriculture: Washington, DC, USA, 2013. Available online: http://websoilsurvey.sc.egov.usda.gov/App/HomePage.htm (accessed on 19 May 2020).

29. NDAWN. North Dakota Agricultural Weather Network; NDAWN Center, North Dakota State University: Fargo, ND, USA, 2016. Available online: http://ndawn.ndsu.nodak.edu (accessed on 30 May 2020).

30. Franzen, D. North Dakota Fertilizer Recommendation: Tables and Equations; North Dakota State University: Fargo, ND, USA, 2013; p. 20. Available online: https://www.ndsu.edu/fileadmin/soils/pdfs/sf882.pdf (accessed on 19 May 2020).

31. Vendrell, P.F.; Zupancic, J. Determination of soil nitrate by transnitration of salicylic-acid. Commun. Soil Sci. Plant Anal. 1990, 21, 1705-1713. [CrossRef]

32. Cataldo, B.A.; Haroon, M.; Schrader, L.E.; Youngs, V.L. Rapid colorimetric determination of nitrate in plant tissue by nitration of salicylic acid. Commun. Soil Sci. Plant Anal. 1975, 6, 71-80. [CrossRef]

33. Olsen, S.R.; Cole, C.V.; Watanabe, F.S.; Dean, L.A. Estimation of Available Phosphorus in Soils by Extraction with Sodium Bicarbonate; U.S. Department of Agriculture Circular: Washington, DC, USA, 1954; p. 19.

34. Warncke, D.; Brown, J.R. Potassium and other basic cations. In Recommended Chemical Soil Test Procedures for the North Central Region; Brown, J.R., Ed.; Publ. 221 (revised); North Central Regional Library: Columbia, MO, USA, 1998; pp. 36-38.

35. Patrignani, A.; Tyson, O. Canopeo: A powerful new tool for measuring fractional green canopy cover. Agron. J. 2015, 107, 2312-2320. [CrossRef]

36. Speirs, J.; Mitchell, W.J. Estimation of nitrogen by Kjeldahl's method note in the ammonia distillation. J. Inst. Brew. 2013, 42, 247-250. [CrossRef]

37. Abrams, S.M.; Shenk, J.; Westerhaus, F.E. Determination of forage quality by near infrared reflectance spectroscopy: Efficacy of broad-based calibration equations. J. Dairy Sci. 1987, 70, 806-813. [CrossRef]

38. SAS Institute. SAS User's Guide: Statistics; SAS Institute: Cary, NC, USA, 2014.

39. Kanemasu, E.T.; Bark, D.L.; Choy, E.C. Effect of soil temperature on sorghum emergence. Plant Soil 1975, 43, 411-417. [CrossRef]

40. Marsalis, M.A. Sorghum Forage Production in New Mexico (Guide A-332); New Mexico State University Cooperative Extension Services: Las Cruces, NM, USA, 2006. Available online: https://aces.nmsu.edu/pubs/ _a/A332/ (accessed on 20 May 2020).

41. Pinthus, M.J.; Rosenblum, J. Germination and seedling emergence of sorghum at low temperatures. Crop Sci. 1961, 1, 293-296. [CrossRef]

42. Chung, Y.S.; Choi, S.C.; Silva, R.R.; Kang, J.W.; Eom, J.H.; Kim, C. Case study: Estimation of sorghum biomass using digital image analysis with Canopeo. Biomass Bioenerg. 2017, 105, 207-210. [CrossRef] 
43. Janowiak, F.; Kaczanowska, K.; Jing, H.C.; Bekele, W.A.; Snowdon, R.J. Metabolic limitations to photosynthetic efficiency of sorghum seedling leaves at low temperature. Procedia Environ. Sci. 2015, 29, 277-278. [CrossRef]

44. Havaux, M. Fluorimetric determination of the genetic-variability existing for chilling tolerance in sweet sorghum and Sudan grass. Plant Breed. 1989, 102, 327-332. [CrossRef]

45. Maughan, M.; Voigt, T.; Parrish, A.; Bollero, G.; Rooney, W.; Lee, D.K. Forage and energy sorghum responses to nitrogen fertilization in central and southern Illinois. Agron. J. 2012, 104, 1032-1040. [CrossRef]

46. Meki, M.N.; Ogoshi, R.M.; Kiniry, J.R.; Crow, S.E.; Youkhana, A.H.; Nakahata, M.H.; Littlejohn, K. Performance evaluation of biomass sorghum in Hawaii and Texas. Ind. Crops Prod. 2017, 103, 257-266. [CrossRef]

47. Martin, F.M. Methods for Research on Soilborne Phytopathogenic Fungi; Singleton, L.L., Milhail, J.D., Rush, C.M., Eds.; APS Press: St. Paul, MN, USA, 1992; p. 3949.

48. Mahmood, A.; Ullah, H.; Ijaz, M.; Javaid, M.M.; Shahzad, A.N.; Honermeier, B. Evaluation of sorghum hybrids for biomass and biogas production. Aust. J. Crop Sci. 2013, 7, 1456-1462.

49. Braconnier, S.; Trouche, G.; Gutjahr, S.; Luquet, D.; Dingkhun, M. Development of new sorghum ideotypes to meet the increasing demand of bioethanol. In Proceedings of the International Conference on Crop Improvement, Ideotyping and Modeling for African Cropping Systems under Climate Change (CIMAC), Stuttgart, Germany, 7-9 February 2011; University of Hohenheim: Stuttgart, Germany, 2011.

50. Tagarakis, A.C.; Ketterings, Q.M.; Lyons, S.; Godwin, G. Proximal sensing to estimate yield of brown midrib forage sorghum. Agron. J. 2017, 109, 107-114. [CrossRef]

51. Foster, A.J.; Kakani, V.G.; Mosali, J. Estimation of bioenergy crop yield and N status by hyperspectral canopy reflectance and partial least square regression. Precis. Agric. 2017, 18, 192-209. [CrossRef]

52. Siemens, M.G.; Schaefer, D.M.; Vatthauer, R.J. Rations for Beef Cattle; Publ. A2387; University of Wisconsin-Ext.: Madison, WI, USA, 1999. Available online: http://learningstore.uwex.edu/assets/pdfs/A2387.PDF (accessed on 20 May 2020).

53. Pedersen, J.F.; Moore, K.J.; Schroth, S.; Walters, D.T. Nitrogen accumulation of six groups of sorghum grown on a municipal biosolids use site. Water Environ. Res. 1995, 67, 1076-1080. [CrossRef]

54. Johnson, C.; Albrecht, G.; Ketterings, Q.; Beckman, J.; Stockin, K. Nutrient Management Spear Program. Agronomy Fact Sheet Series; Fact Sheet 2; Cornell University Cornell Coop. Ext.: Middletown, NY, USA, 2005. Available online: http://nmsp.cals.cornell.edu/publications/factsheets/factsheet2.pdf (accessed on 20 May 2020).

55. Kaur, J.; Cihacek, L.J.; Chatterjee, A. Estimation of nitrogen and sulfur mineralization in soils amended with crop residues contributing to nitrogen and sulfur nutrition of crops in the North Central U.S. Commun. Soil Sci. Plant Anal. 2018, 49, 2256-2266. [CrossRef]

56. Lee, D.; Owens, V.N.; Boe, A.; Jeranyama, P. Composition of Herbaceous Biomass Feedstocks; North Central Sun Grant Center, South Dakota State University: Brookings, SD, USA, 2007; pp. 1-16.

57. Parish, J.A.; Rhinehart, J.D. Fiber in BeefCattle Diets; Mississippi State University Ext. Serv.: Starkville, MS, USA, 2008. Available online: https://extension.msstate.edu/sites/default/files/publications/publications/p2489.pdf (accessed on 20 May 2020).

58. Stefaniak, T.R.; Dahlberg, J.A.; Bean, B.W.; Dighe, N.; Wolfrum, E.J.; Rooney, W.L. Variation in biomass composition components among forage, biomass, sorghum-sudangrass, and sweet sorghum types. Crop Sci. 2012, 52, 1949-1954. [CrossRef]

59. Zhao, X.; Zhou, H.; Sikarwar, V.S.; Zhao, M.; Park, A.H.A.; Fennell, P.S.; Shen, L.H.; Fan, L.S. Biomass-based chemical looping technologies: The good, the bad and the future. Energy Environ. Sci. 2017, 10, 1885-1910. [CrossRef]

(C) 2020 by the authors. Licensee MDPI, Basel, Switzerland. This article is an open access article distributed under the terms and conditions of the Creative Commons Attribution (CC BY) license (http://creativecommons.org/licenses/by/4.0/). 